\title{
PROPAGACE MUZEA KLEMENTA GOTTWALDA POHLEDEM PLAKÁTŮ

\section{JOLANA TOTHOVÁ}

\section{ABSTRAKT/ABSTRACT:}

Cílem článku je formou rozboru plakátů Muzea Klementa Gottwalda, v kontextu jeho celkové propagace, charakterizovat hlavní rysy mediální tváře této politicko-výchovné instituce na tradičním tištěném médiu. $\mathrm{V}$ př́ípadě Muzea Klementa Gottwalda je ustálena řada obecných představ ovlivněných osobními zážitky veřejnosti a procesem určité formy „vytěsnění" po pádu režimu státního socialismu. Proto je důležité postupným poznáváním jednotlivých témat spojených s jeho činností a užívaných postupů muzejní prezentace obhájit kontinuitu zachování hodnot jím vytvořené sbírky. Předkládané téma je součástí probíhajícího výzkumu československých ústředních stranických muzeí prostřednictvím nového zpracování jejich sbírkových, archivních a knihovních fondů ve Sbírce Muzea dělnického hnutí v Národním muzeu.

\section{Promotion of the Klement Gottwald Museum through the medium of posters}

The article analyses the posters of Klement Gottwald Museum and in its overall promotion context it characterises the main features of how this political-educational institution was presented on a traditional printed medium. The public image of Klement Gottwald Museum is associated with many general beliefs influenced by people's personal experiences and by a sort of "crowd-out" after the fall of socialism. Therefore it is important to defend the continuous preservation of values of this museum's collection by gradual learning about individual thematic issues connected with its activity and applied methods of museum presentation. The presented topic is part of a comprehensive research on Czechoslovak central political party museums including a new processing of their collections, archives and libraries in the form of the Working Class Movement Museum Collection in the National Museum.

\section{KLÍČOVÁ SLOVA/KEYWORDS:}

\section{Muzeum Klementa Gottwalda -} propagace - plakát - brožura politicko-výchovná instituce Klement Gottwald Museum promotion - poster - booklet political-educational institution

„Vzhledem $k$ novému rozdělení práce bude věnováno daleko více péče:

a/ Ideologické práci Musea V. I. Lenina a Musea počátků čs. dělnického hnutí. Práce lektorů bude pravidelně projednávána a soustavně zvyšována její úroveň.

b/ Soustavnému zvyšování návštěvnosti obou museí, pomocí rádné kontroly plnění usnesení pol. sekretariátu o popularisaci.

c/ Plnému a plánovitějšśmu využití oken v Museu Klementa Gottwalda na poli boje proti masarykismu, sociáldemokratismu, náboženství a odkazu Lenina, Stalina a Gottwalda."

1 Národní archiv (dále NA) v Praze. Fond 1065 Ústav dějin KSČ (dále ÚD KSČ), kart. 114, a. j. 800.
Plakát v současnosti není hlavním médiem propagace kulturních institucí ani informací o dění $\mathrm{v}$ kultuře. Nebyl jím již ani při vzniku ústředních stranických muzeí, kdy byl považován za „běžný“ prostředek propagace. ${ }^{2}$ Důraz byl kladen na spolupráci s masovými médii (tiskem, rozhlasem a později televizí) a zvláště na prrímý kontakt $s$ vedením organizací s velkou členskou základnou, často formou instrukcí z vedení vládní strany. Účel celé propagace byl spojován s návštěvností jako hlavním ukazatelem efektivity. Tento přistup vlastně vytěsnil vydávání plakátů $\mathrm{k}$ propagaci muzea jako instituce téměř na minimum. Přesto si zaslouží náležitou pozornost a zařazení mezi důležité prameny poznání činnosti a společenské role našich muzeí.

Právě probíhající výzkum činnosti a muzejní prezentace dvojice ústředních stranických muzeí Muzea V. I. Lenina (dále MVIL) a Muzea Klementa Gottwalda (dále MKG), včetně jeho pobočky, Muzea Julia Fučíka (dále MJF), otevírá celou řadu témat. ${ }^{3}$ Jedním $\mathrm{z}$ nich je

\footnotetext{
Závěry z projevu s. Nečáska [toho času tajemník ÚV KSČ a člen Ideové rady MKG] k pracovníkům agit. prop. oddělení. 22. 6. 1953.

2 „K popularisaci musea [MVIL, roku 1953] bylo použito samozřejmě i běžných prostředků jako plakátů, ...". NA v Praze. Fond 1065 - ÚD KSČ, kart. 114, a. j. 815. Zpráva o činnosti musea MVIL za rok 1953, s. 7. Z řady záznamů o strategiích popularizace muzeí pod správou ÚD KSČ je jasný tlak na řízenou agitaci v kolektivech a dobová masmédia. Naopak plakáty jsou zmiňovány nepravidelně a jsou vnímány jako samozřejmá součást poloveřejného prostoru (škol, dopravních prostředků, jídelen, studoven).

3 Text vznikl v rámci projektu „Muzeum dělnického hnutí v 21. století. Prezentace práce s muzejní sbírkou doby státního socialismu a způsoby užití jejího materiálu k potrebám odborné a široké veřejnosti“, podpořeného grantovým programem apli-
} 
dobová popularizace nového muzejního výkladu čs. dějin, konkrétně formy a podoba centrálně řízené propagace prominentní kulturní instituce. Zachované části fondů trojrozměrných předmětů, archiv i knihovna jmenovaných institucí tvoří od roku 2014 samostatnou Sbírku Muzea dělnického hnutí v Národním muzeu. ${ }^{4}$ Součástí fondu Plakáty je soubor věnovaný muzeím, ostatním převážně československým kulturním institucím a velkým výstavám. $\mathrm{V}$ průběhu tř́ídění se otevřel pohled na mozaiku tištěné mediální tváře MKG, které bylo př̀i svém vzniku pasováno do role tvůrce nové prezentace soudobých dějin a praktického tvůrce metodických materiálů a aktivit kulturně-historické propagandy.

Hlavním cílem článku je shrnout a, v kontextu dostupných pramenů a celkové propagace instituce, zhodnotit formu, obsah a relativní kvalitu plakátů MKG. V úvodní části jsou v rozsahu nezbytném pro kontext sledovaného tématu shrnuty informace o muzeu a jeho pobočkách (historie, expozice, výstavy a další aktivity) a přehled forem propagace MKG. Tištěné propagační materiály krom plakátů si vzhledem k svému rozsahu a nezbytnosti jejich analýzy zaslouží samostatný výstup, takže nejsou podrobněji řešené. Jsou však zahrnuty do souvislostí s plakáty.

Druhá část textu je věnována poznání mediální tváře MKG na plakátech instituce. Základní otázkou stanovenou na počátku kompletace podkladů bylo zařazení plakátů MKG do žánrových skupin - kulturní či politický? Kromě samostatné

kovaného výzkumu a vývoje národní a kulturní identity (NAKI II) č. DG18P02OVV045.

4 Po roce 1990 byly spojeny do jednoho celku a spravovány nestátním subjektem Muzeum dělnického hnutí, který sbírku daroval Národnímu muzeu. Přebírání probíhalo v letech 2014 až 2017. Informace o rozsahu a obsahu jednotlivých fondů SMDH publikovány v článku TOTHOVÁ, Jolana. Sbírka Muzea dělnického hnutí - rozsáhlý soubor předmětů, archiválií a knih. Muzeum: Muzejní a vlastivědná práce, 2017, roč. 55, č. 2, s. 16-26.

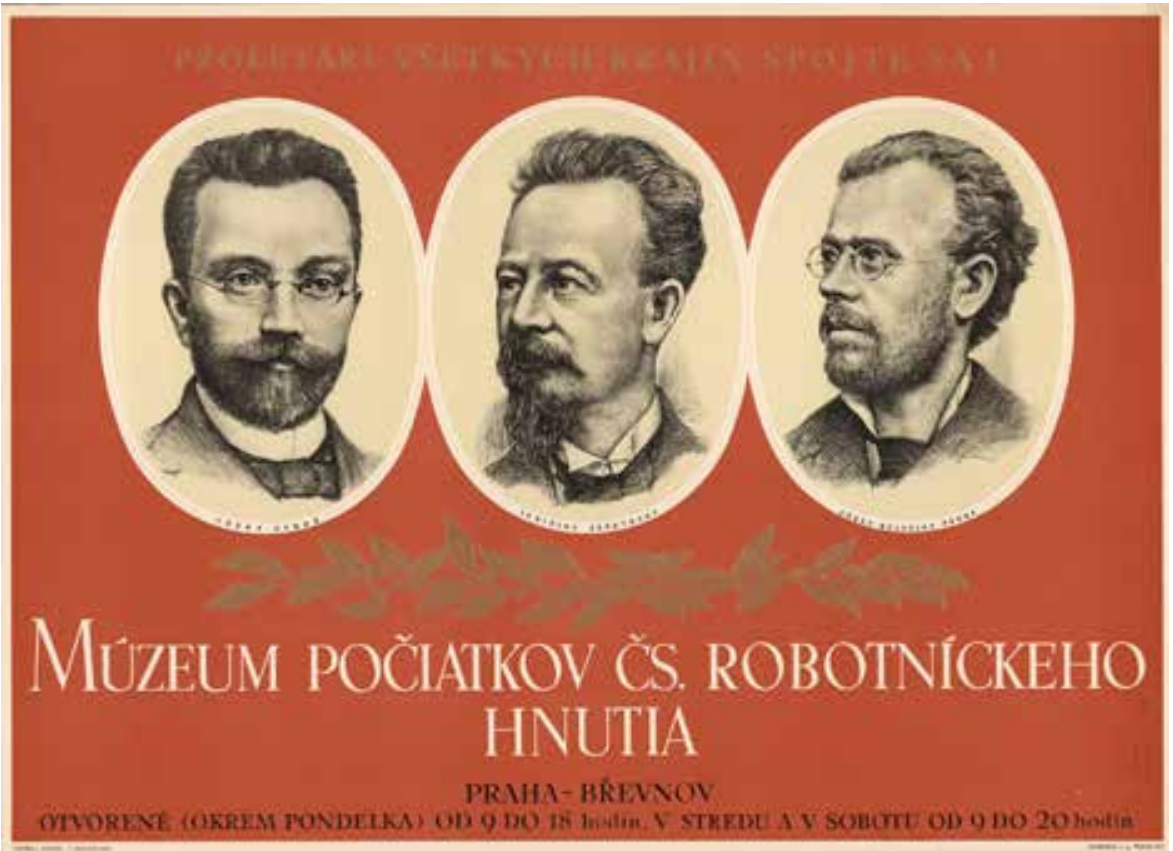

Obr. 1: Plakát Múzeum počiatkov čs. robotníckeho hnutia (autoři Jaroslav Kaiser a Jindřich Koukolský, nakladatelstvím Svoboda, 1953). Národní muzeum, Sbírka Muzea dělnického hnutí, H11P-309.

části článku jsou konkrétní znaky aspektů propagandy součástí rozboru plakátů.

Plakáty MKG se dají dělit podle kritéria propagovaného obsahu (muzeum - expozice; výstavy). Výstavy jsou ještě děleny na konané $v$ MKG a výstavy putovní, respektive $\mathrm{v}$ regionech ve spolupráci s MKG. Programové plakáty MKG nevydávalo, až v 80. letech se objevují letáky se soupisem akcí na jeden měsíc. Vzhledem k rozsahu tématu a s ohledem na nekompletní soupis výstav ${ }^{5}$ se článek omezuje pouze na plakáty propagující instituci a expozici.

Samotná prezentace plakátů vydaných pro propagaci muzea a vybraných poboček je založena na práci $s$ jejich obsahem a podobou v rámci kvalitativní analýzy srovnání s pla-

\footnotetext{
5 Přestože se zachovalo velké množství výstavních plakátů, tak se v průběhu kompletace nepodařilo vytvořit základní soupis výstav a zřejmě řada plakátů se bude ještě muset dohledat v jiných fondech než SMDH. Chybějící hlavní zdroj informací, fond MKG v Archivu Národního muzea, je však ještě na takovýto výzkum nedostatečně utříděn. Zachovaná agenda Odboru muzeí a výstav ÚD KSČ v NA v Praze podrobnosti o výstavách MKG ani plakáty neobsahuje.
}

káty jeho internacionálně zaměřeného sourozence - MVIL. Původní předpoklad srovnání s větším okruhem muzejních institucí obdobného typu (Národní muzeum, Památník národního písemnictví, Památník Terezín ad.) se ukázal jako problematicky realizovatelný bez souvislostí vývoje plakátové prezentace těchto institucí. Bohužel doposud není věnována větší pozornost vývoji tištěné propagace kulturních institucí. Plakáty výše uvedených institucí nejsou doposud uceleněji zhodnoceny. Jen ojediněle, jako obrazová př́loha, jsou v materiálech $\mathrm{k}$ výročím ${ }^{6}$ a často nejsou ani zkompletovány. ${ }^{7}$ Další počáteční zadání - zařazení plakátů MKG do kontextu tvorby jejich autorů se také ukázalo jako nadbytečné.

6 Panelová výstava Šedesát let Památníku národního písemnictví. 1953-2013 obsahuje foto jednoho z prvních plakátů PNP. Publikace k výročím neobsahují ukázky plakátů institucí: ŠTURSOVÁ, Květoslava. Tyršovo muzeum tělesné výchovy a spor tu. Praha: Národní muzeum, 2003; MUNK, Jan. 70 let Památníku Terezín. Terezín: Petr Oswald OSWALD, 2017. ISBN 978-80-87242-29-2.

7 Jako příklad lze uvést Národní muzeum (dále NM), jehož plakáty jsou uloženy v několika archivních a jednom sbírkovém fondu. V souvislosti s kompletací seznamu výstav NM jsou v současnosti plakáty v Archivu NM tříděny a zpracováván jejich soupis. 
U řady plakátů není znám autor. Navíc se ukázalo, že i u významných grafiků a typografů jsou jejich návrhy plakátů stranických muzeí (MKG i MVIL), i přes jasně viditelnou kvalitu, tak odlišné od jejich převažující tvorby, že se bohužel vlastně jedná spíše o produkty obživy, odrážející úzké zadání jen s minimální možností autorského vkladu. Naopak v průběhu zpracování vyplynula zajímavá zjištění o vizuální podobě propagace MKG a jeho odlišnosti od MVIL, přestože obě instituce nesla jména osobností a měla společné ideové i správní vedení.

\section{Muzeum Klementa Gottwalda v Praze}

\section{Muzeum Klementa Gottwalda} vzniklo v roce 1952 jako zcela nová instituce usnesením vlády, nejprve jako Museum revolučního hnutí, ${ }^{8}$ a až následně po smrti prvního dělnického presidenta pojmenovanou jeho jménem. ${ }^{9}$ Expozice byla otevřena 23. listopadu 1954 v neorenesanční budově bývalé spořitelny v Rytířské ulici v Praze, kde sídlil i Ústav dějin Komunistické strany Československa (dále KSČ).

V Řádu vědecké práce MKG je stanoveno jasné poslání: „MKG je politicko-výchovným ústavem, který pod ideologickým vedením Ústavu dějin KSČ plní tyto hlavní úkoly: 1) popularizuje ve spojitosti s denními úkoly a usneseními strany a vlády dějiny dělnického hnutí a historii KSČ, jako uplatnění marxismu-leninismu v praxi. Je významným pomocníkem při prohlubování studia účastníků

8 Archiv Národního muzea (dále ANM), fond Sbír ka Muzea dělnického hnutí (dále SMDH), nezpracováno. Oznámení vlády o zř́zení Musea revolučního hnutí v Praze podle usnesení vlády ze dne 29. dubna 1952; Národní archiv (dále NA) v Praze. Fond 1065 - ÚD KSČ, kart. 113, a. j. 815. Usnesení politického sekretariátu ÚV KSČ z 2. dubna 1952 a usnesení vlády z 29. dubna 1952.

9 O přejmenování MKG a určení jeho poboček rozhodla Státní komise pro uctění památky Klementa Gottwalda na své 1. schůzi 26. 5. 1953. „... po stránce ideologické bude provedena jen částečná změna" /muzea/ - pozn. autora. NA v Praze. Fond 1065 - ÚD KSČ, kart. 113, a. j. 812. stranického školení. 2) Pečuje o výstavbu a řílí provoz všech poboček, poskytuje jim pomoc při plnění politicko-osvětových úkolů. 3) Poskytuje jak ideovou, tak organizační pomoc masovým organizacím a institucím při pořádání exposic a vydávání materiálu z čsl. dělnického hnutí a historie KSČ, ze života a díla Klementa Gottwalda." 10

První pobočkou, ještě Musea revolučního hnutí, bylo od roku 1952 Museum počátků československého dělnického hnutí v Praze - Břevnově, v domě U Kaštanu. ${ }^{11}$ Malá expozice byla otevřena již 4. dubna 1953 u př́ležitosti 75. výročí konání tak zvaného břevnovského sjezdu. ${ }^{12}$ Muzeum, i přes připravovanou přestavbu expozice a stále relativně vysokou návštěvnost, bylo zrušeno $\mathrm{v}$ roce 1962 , protože jeho roli převzaly moderní expozice MKG. ${ }^{13}$ Budova byla předána Okresnímu národnímu výboru v Praze 6, který zde v 70. letech zmodernizoval pamětní síň na expozici Průkopníci socialismu. ${ }^{14}$

Až do počátku 60. let byl pobočkou MKG i rodný dům Klementa Gottwalda v Dědicích, otevřený v roce 1955. Celkem razantně zrekonstruovaná usedlost byla přestavěna do idealizované podoby k roku 1896, kdy se zde dle oficiálních interpretací president narodil. Společně s rodným domem byla veřejnosti zpřístupněna i světnička v Rousíno-

10 NA v Praze. Fond 1065 - ÚD KSČ, kart. 114,
a. j. 796. Řád vědecké práce Musea Klementa
Gottwalda (3. 1. 1956).

11 NA v Praze. Fond 1065 - ÚD KSČ, kart. 114, a.j. 838. Návrh na založení Musea počátků československého dělnického hnutí, ... vládní usnesení ad.

12 Museum počátků čs. dělnického hnutí. Praha Břevnov, nedatováno. Brožura.

13 NA v Praze. Fond 1065 - ÚD KSČ, kart. 114, a. j. 843.

14 NOVOTNÝ, Karel. Průkopníci socialismu: prưvodce expozicí v národním kulturním památníku Kaštan. Praha: Obvodní národní výbor, 1979; Průkopníci socialismu v českých zemích: průvodce expozicí v národním kulturním památníku Kaštan. Praha: Obvodní národní výbor v Praze 6, 1979, vol. 1. vě, kde pobýval v letech 1920-21. ${ }^{15}$ Správa rodného domu byla převedena na Muzeum dělnického hnutí v Brně a následně přešla pod Muzeum Vyškovska. V roce 1971 rozhodl jihomoravský Krajský výbor KSČ o přebudování rodného domu na Památník Klementa Gottwalda. ${ }^{16}$

Jako pobočka MKG fungovala i Výstava darů Klementu Gottwaldovi v Lobkovickém paláci na Pražském hradě, přístupná od 23. února 1952 do října 1958. ${ }^{17}$ Vystavené dary byly následně předány muzeím. ${ }^{18}$

Nejmladší pobočka MKG vznikla až v roce 1987. Muzeum Julia Fučíka, jehož sbírkový fond vycházel z pozůstalosti manželů Fučíkových, bylo otevřeno v budově Galerie Hollar na Smetanově nábřeží v Praze roku $1988 .^{19}$

Krátce byl pobočkou i dům redakce komunistických časopisů ve Vrútkách. ${ }^{20}$ Projednávalo se i zřízení poboček MKG v Brně a Ostravě, kde nakonec vznikla samostatná regionální stranická muzea. ${ }^{21}$

15 NA v Praze. Fond 1065 - ÚD KSČ, kart. 113, a. j. 812. Světnička byla uzavřena v roce 1985 , kvůli rekonstrukci objektu.

16 Podrobně viz FRANĚK, Otakar (ed.). Rodný domek Klementa Gottwalda v Dědicích; světnička Klementa Gottwalda v Rousínově: [sborníček]. 1. vyd. Praha: Muzeum Klementa Gottwalda, 1959; FRANĚK, Otakar a Zbyněk STRÁNSKÝ. Památník Klementa Gottwalda v Dědicích: [průvodce]. Brno: Muzeum dělnického hnutí, 1978.

17 Podrobněji viz SOMMER, Vítězslav. Angažované dějepisectví: stranická historiografie mezi stalinismem a reformním komunismem (1950-1970). 1. vyd. Praha: Nakladatelství Lidové noviny, 2011, s. $86-88$.

18 Kromě MKG dary v celkem velkém počtu přešly i do Národního muzea, Technického muzea v Brně apod. Národní muzeum. Sbírka Muzea dělnického hnutí (dále NM. SMDH). Kniha darů presidentu Klementu Gottwaldovi.

19 K tématu viz ELIÁŠOVÁ, Libuše. Gusta Fučíková a pozůstalost Julia Fučíka. In PODHAJSKÝ, František A. (ed.). Julek Fuč́́k - věčně živý! 1. vyd. Brno: Host, 2010, s. 77-92.

20 NA v Praze. Fond 1065 - ÚD KSČ, kart. 114, a. j. 822. Zdůvodnění vydání v rozpočtu MKG za rok 1954, 21. 9. 1953.

21 NA v Praze. Fond 1065 - ÚD KSČ, kart. 114, a. j. 822. Dopis min. Z. Nejedlému s rozpisem finančních potřeb na nejdůležitější úkoly ÚD KSČ na roky 1956 - 1960, 21. 12. 1955; NA v Praze. Fond 1065 - ÚD KSČ, kart. 114, a. j. 813. Schůze 
První expozice MKG z roku 1954 prezentovala ve dvaceti sálech revoluční boj Čechů a Slováků až do tehdejší současnosti budování socialismu. Již na přelomu 50. a 60. let byly ideově upraveny nebo zcela nově rozděleny části pro období 1918 až 1945. Po uzavření expozice v roce 1968 byla provedena její celková reinstalace v letech 1972 až 1974. Poslední větší reinstalace, spíše modernizace a přeformulování výkladu dle závěrů XVI. sjezdu KSČ, jemuž byl dokonce věnován jeden výstavní sál, byla provedena $\mathrm{v}$ roce 1981 .

Expozice doplňovaly výstavy především tématy vykládajícími občanům průběh a význam akcentovaných historických událostí a vedoucí úlohy strany (např. 1960 - Pražské povstání v květnu 1945, ${ }^{22} 1964$ - Od Mnichova k 15. březnu, 1966 - XIII. Sjezd Komunistické strany Československa, 1968 - Únor 1948, 1981 - 60 let KSČ vítězná cesta). ${ }^{23}$ Témata dále reagovala na mezinárodní situaci z pohledu socialistického bloku (1956 - Polský lid v boji za svobodu a socialismus, 1959 - Nejde jen o Berlín. Výstava o západoněmeckém imperialismu a revanšismu, 1963 - Svobodná Kuba, 1966 - Mír Vietnamu). Výstavy o současnosti a vlastně i perspektivě budoucnosti se zaměřovaly na vývoj socialistické společnosti formou konkrétních příkladů rozvoje průmyslových podniků, životní úrovně obyvatel, modernizaci venkova apod. (např. 1960 - Ostrava $v$ barevné fotografii, ${ }^{24}$ 1962 - výstava barevných fotografií Tvář dnešního Slovenska, 1979 -

sekretariátu ÚV KSČ. Návrh na zřízení pobočky MKG v Brně a Ostravě, 20. 1. 1956.

22 Návštěvnost cca 30 tis. NA v Praze. Fond 1065 - ÚD KSČ, kart. 114, a. j. 815. Zpráva o činnosti MKG za rok 1960.

23 Uvedený výběr výstav vychází z neúplného lístkového seznamu spisové agendy k výstavám a expozicím MKG (ANM, fond $S M D H$, nezpracováno) a z tiskovin v SMDH, fond Plakáty.

24 Návštěvnost za 6 týdnů cca 10 tis. NA v Praze. Fond 1065 - ÚD KSČ, kart. 114, a. j. 815. Zpráva o činnosti MKG za rok 1960.
30 let socialistického zemědělství $v$ Československu). Na repertoáru nechyběla výročí osobností (především K. Gottwalda a A. Zápotockého). Objevovala se i úzce tematicky zaměřená umělecká tvorba (např. 1964 - Politická grafika W. A. Schlossera, 1965 - Skupina 9 plakáty grafika, 1966 - Německá revoluční grafika, 1974 - Česká sociální grafika dvacátých let, 1981 - Kultura tvorba umění $k X V I$. sjezdu KSČ).

V činnosti muzea byl kladen velký důraz na lektorské výklady a doprovodný program. Samozřejmostí se už od počátku staly besedy, promítání dokumentárních filmů. V návaznosti na spolupráci s kolektivy se v muzeu konaly slavnostní akce - pionýrské sliby, předávání resortních vyznamenání či občanských průkazů.

Zároveň MKG prakticky fungovalo jako metodické pracoviště muzejní prezentace moderních čs. dějin. Nejen, že jeho expozice byla vlastně neustále aktualizována až do současnosti, ale jeho pracovníci se stejně jako externí historikové účastnili přímo příprav expozic a výstav v regionech (od muzeí až po síně tradic). ${ }^{25}$

MKG, muzeum dějin KSČ a revolučních bojů čs. lidu (po roce 1974 upraveno na dějin revolučního dělnického hnutí), zaniklo k 31. lednu 1990. Ovšem díky zachování většiny jeho fondů $v$ rámci jednoho celku, lze průběžně v dostatečném časovém odstupu pracovat $s$ artefakty i archiváliemi v novém kontextu a zároveň poznávat koncepce a vývoj vzorového muzejního pracoviště své doby. Jako ústřední stranické muzeum, instituce podléhající přímé ideové i správní kont-

25 Např. v roce 1960 se MKG podílelo na vybudo vání památníku B. Šmerala v Třebíči vypracováním scénáře a pomáhalo při instalaci památníků A. Staška a I. Olbrachta v Semilech. Pracovníci připravili v závodech, školách a organizacích 26 přednášek a besed a publikovali 10 článků v časopisech. NA v Praze. Fond 1065 - ÚD KSČ, kart. 114, a. j. 815. Zpráva o činnosti MKG za rok 1960.

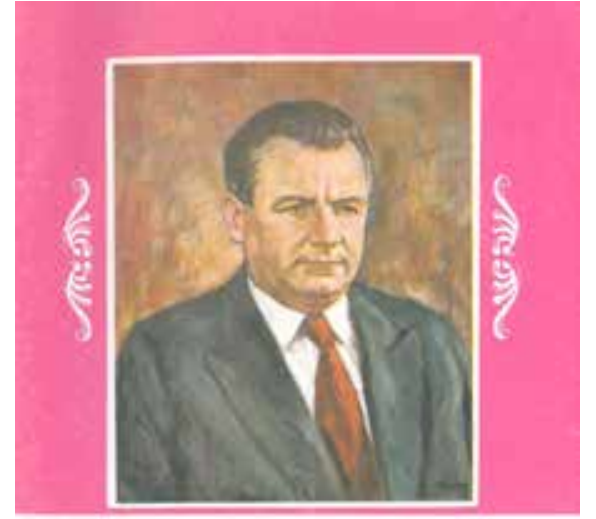

MTOZEUTMI KLEMTENTA GOTT WVALDA V PRAZE
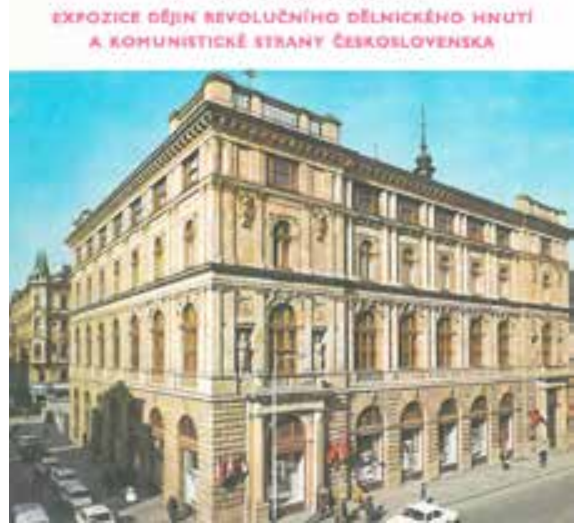

Obr. 2: Brožura Muzeum Klementa Gottwalda v Praze. Expozice dějin revolučního dělnického hnutí a Komunistické strany Československa. Praha: ORBIS, nedatováno (po 1974)

role KSČ, patřilo do úzce tematicky profilované složky kulturních institucí, jejichž hlavním úkolem byla aktivizace společnosti a průběžná agitace v intencích vládní stranou schválených témat současnosti a výhledů do budoucnosti. ${ }^{26}$ Tomuto zaměření a silné ideové kontrole plně odpovídala obsahová náplň činnosti muzea i jeho propagace.

26 Ústřední stranická muzea byla pod ideovým vedením ÚD KSČ a navíc při jejich zřízení byla řízením práce a ideového pojetí instalací pověřena ideová rada. Ideová rada MKG k 23. 3. 1954 měla složení: dr. Zdeněk Nejedlý, Václav Kopecký, gen. Čeněk Hruška, prof. Ladislav Štoll, Jindřich Veselý, František Pór, dr. Jan Pachta, dr. Štefan Rais, dr. Josef Pošmourný a František Nečásek. NA v Praze. Fond 1065 - ÚD KSČ, kart. 114, a. j. 815. Zpráva pro členy Stání komise pro uctění památky Klementa Gottwalda, 23. 3. 1954. 


\section{Pojd'te s námi do muzea - propagace MKG}

Je samozřejmostí, že každá kulturní instituce musí mít účinnou reklamní kampaň odvislou od svého zaměření, územního působení (regionální, celostátní) a rozsahu cílové skupiny návštěvníků. Propagace muzea a jeho činnosti byla a je nedílnou součástí jeho tváře směrem $\mathrm{k}$ veřejnosti.

Téma stranických muzeí je úzce spjaté již s poválečnými pražskými výstavami. Což stoprocentně platí i pro propagaci. Počáteční těsně poválečné výstavní projekty (napřr. v roce $1946-K S C ̌$ v boji za svobodu, ${ }^{27}$ Český národ Rudé armádě (výstava obrazů, plastik a grafik; a výstava věcných darů) ${ }^{28}$ se rozvinuly do masovějších a především již státním aparátem řízených aranžmá. V dobových médiích hojně propagované výstavy roku 1949 Výstava dějin revolučních bojů, ${ }^{29}$ zahájená v předvečer IX. sjezdu KSČ v Památníku osvobození v Praze na Vítkově (dnešní Armádní muzeum Žižkov), a Československý lid a jeho kraj v životě, práci a zápasu. Výstava obrazů a soch z let 1918-49 v Jízdárně Pražského hradu, ${ }^{30}$ následované roku 1951 taktéž v Památníku osvobození výstavou Tricet let KSČ. ${ }^{31}$

\footnotetext{
27 NA v Praze. Fond 1065 - ÚD KSČ, kart. 115, a. j. 845. Pamětní knihy výstavy.

28 ŠANDA, Jaroslav a Anna MASARYKOVÁ (eds.). Český národ Rudé armádě: seznam děl výtvarného umění věnovaných českými umělci Rudé armádě $z$ vděčnosti za osvobození a odevzdaných $k$ výroč nímu dni založení Rudé armády 23. února 1946. Praha: Společnost pro kulturní a hospodářské styky s SSSR, 1946. Plakát k výstavě vytvořil Emanuel Famíra.

29 Propagační materiály: Výstava dějin revolučních bojů. Praha: Svět v obrazech, 1949; LORIŠ, Jan a Jiří MÜLLER (eds.). Výstava dějin revolučních bojů: Praha - Památník osvobození. Květen-srpen 1949: Stručný průvodce. Praha: ÚV KSČ - kulturní a propagační odd., 1949; Sborník výstavy dějin revolučních bojů. Praha: Kulturní a propagační oddělení sekretariátu ÚV KSČ, 1949.

30 Československý lid a jeho kraj v životě, práci a zápasu. Praha: Ministerstvo informací a osvěty, 1949.

31 NA v Praze. Fond 1065 - ÚD KSČ, kart. 116, a. j. 858-862. Spisy ÚD KSČ k přípravě a konání výstavy; Výstava Třicet let KSČ. Praha: Ústav dějin KSČ, 1951.
}

Úspěch a množství nashromážděných materiálů z výstav na Vítkově uspíšil aktivitu stranických orgánů zřídit nové muzejní instituce.

Většina zapůjčených dokumentů a artefaktů ze jmenovaných výstav z Vítkova se stala základem sbírkového fondu Musea revolučního hnutí a archivu ÚD KSČ. Jasná ideová návaznost nových muzeí na tyto výstavy osvětluje i stejný přístup $\mathrm{k}$ propracované týmové přípravě s dozorem z nejvyšších míst (týmy historiků a dokumentátorů podávající zprávy o práci na expozici ideovým radám, složeným z vysokých funkcionářů strany a vlády), medializaci a chtění masovosti - tlak na zvyšování návštěvnosti, podněty pro články v tisku a prezentaci v rozhlase. ${ }^{32}$

\section{Cílená propagace byla obecně} u stranických muzeí podrobně monitorována a plánována společně s návštěvností a kvalitou práce lektorů. Kromě pravidelných zpráv o činnosti byla hodnocena i při průběžných prověrkách práce v MKG. ${ }^{33}$ Zvláště na skupinové návštěvy byla po celou dobu jeho existence cílena oficiální komunikace a spolupráce s organizacemi (SČSP, SSM, ROH, LM apod.), školami, závody, armádou a to vedená i přes krajská či okresní vedení strany. Kromě osobních jednání, dopisů s výzvami k návštěvě, zasílání propagačních materiálů, realizovali především lektoři a odborní pracovníci besedy v regionech. Zajímavou ukázkou dokládající zacílení na skupinové návštěvy je reklama „MKG pomocník večerních škol a kroužků dějin KSČ ve stranickém školeni" otištěná se čtyřbodovým výčtem důvodů návštěvy a informacemi o muzeu na

\footnotetext{
32 K výstavám: SOMMER, Vítězslav. Angažované dějepisectví: stranická historiografie mezi stalinismem a reformním komunismem (1950-1970). 1. vyd. Praha: Nakladatelství Lidové noviny, 2011, s. 76-88 (k propagaci vedenou ÚD KSČ s. 86). 33 Např. NA v Praze. Fond 1065 - ÚD KSČ, kart. 114, a. j. 816. „Zpráva o závěrech prověrky práce v MKG, 30. 4. 1958“, kde bylo do nové struktury vedoucích pracovníků navrženo řízení propagace prvním vědeckým pracovníkem.
}

zadní stravě obálky brožury Dějiny KSČ. ${ }^{34}$ Pro srovnání - řízený nábor skupinových návštěvníků byl ještě více propracován v Muzeu V. I. Lenina, které spolupracovalo například s Čedokem a vydalo s ním i svou první brožuru o muzeu. ${ }^{35}$ K 1. 1. 1958 se MKG a MVIL, stejně tak i Muzeum dělnického hnutí Brněnska, stala výlučně stranickými muzei, ${ }^{36}$ což je nejen $v$ jejích expozicích a výstavních projektech, ale i v propagaci, ještě více odklonilo od ostatních muzeí do sféry politické a ideově-výchovné.

Druhou úrovní propagace byla přímá prezentace médii - audiovizuálními (rozhlas, film, televize) a tištěnými (domácí a zahraniční tisk, plakáty, drobné tiskoviny).

Již v roce 1955 vznikl krátký barevný dokumentární film Museum Klementa Gottwalda o jeho založení a historickém i uměleckém vybavení. ${ }^{37}$ Reportáže v rozhlase, ve filmových týdenících a později i v televizních zprávách se staly pravidelnou součástí průběžné propagace MKG. Veřejnosti byly předkládány upoutávky především na výstavy a významná výročí či informace o delegacích. ${ }^{38} \mathrm{Ve}$ vzdělávacích pořadech pro televizi ska - vedoucí síla při budování vyspělé socialistické společnosti. 1. vyd. Praha: Státní nakladatelství politické literatury, 1960. Vyšla v nákladu 66000. 35 NOUZA, Oldřich et al. Museum V. I. Lenina v Praze: [sborník]. Praha: Čedok, 1953. „Čedok vydal v desetitisícovém nákladu [...] Brožuru rozešle svým odbočkám, dva tisíce dá do komise Museu V. I. Lenina a tři tisíce prevezme ministerstvo školství, jež je rozešle ředitelstvím škol jako pomůcku pro př́pravu žactva před návštěvou musea." Cit. z NA v Praze. Fond 1065 - ÚD KSČ, kart. 114, a. j. 800. Zpráva MVIL za rok 1953.

36 ANM. Fond $S M D H$, nezpracováno. Výpis z perspektivního plánu Ústavu dějin KSČ, schváleného sekretariátem ÚV KSČ dne 19. srpna 1959. Hospodářská správa přešla z ministerstva školství a kultury (vykonávána skrze ÚD KSČ, jenž bylo pověřeno ideovým vedením již od vzniku muzeí) na sekretariát ÚV KSČ.

37 Více viz Museum Klementa Gottwalda. Československo, 1955, 16 min. In Česko-Slovenská filmová databáze [online]. [cit. 2019-11-22]. Dostupný z www: <https://www.csfd.cz/film/225723-museum-klementa-gottwalda/komentare/>

38 Pořady vyrobené Československou televizí a Krátkým filmem Praha jsou prrístupné v Archivu 
a školy se MKG objevovalo v roli místa paměti budování socialistické společnosti, kde přesvědčivě působí síla artefaktu a výkladu. Případně muzeum poskytovalo archivní materiály k natáčení.

Základem propagace byl samozřejmě tisk (krátké zprávy a články v časopisech), u MKG především tuzemský, v MVIL se řešil řízeně i tisk zahraniční. V roce 1960 vyšlo o činnosti MKG celkem 140 zpráv a 26 článků. ${ }^{39}$ Pro ilustrování rozsahu propagace $\mathrm{v}$ tisku i $\mathrm{v}$ letech s uzavřenými expozicemi: ve 313 tuzemských titulech sledovaných Pražskou informační službou otištěno 76 (1972) a 56 (1973) zpráv a článků. V roce 1972 se $\mathrm{v}$ téměř polovině $\mathrm{z}$ nich prezentovala výstava Leningrad - město Leninovo - město hrdina, která se v MKG konala od ledna do dubna 1972. Následujícího roku byly v tisku zveřejňovány články především o probíhající rekonstrukci muzea, předpokládaných termínech otevření expozic, o výstavách, na nichž MKG spolupracovalo, a velké množství nekrologů ředitele. ${ }^{40}$

Stejně jako ostatní muzea i MKG vydávalo propagační brožury o muzeu s popisy expozice, průvodce jednotlivých částí expozice, metodické brožury ${ }^{41}$ a drobné tiskoviny (pohledy, rozkládačky s fotografiemi, vstupenky). $\mathrm{K}$ výstavám kromě plakátu vznikaly pozvánky a objevují se i drobné katalogy. Zvláště brožury se typem i provedením často shodují s tiskovinami MVIL, které však navíc kromě vydávání časopisu Zpravodaj Muzea Vladi-

\section{a programových fondech České televize. Fond} audiovizuálních záznamů.

39 NA v Praze. Fond 1065 - ÚD KSČ, kart. 114, a. j. 815. Zpráva o činnosti MKG za rok 1960. 40 ANM. Fond SMDH, nezpracováno. MKG výstřižky 1972 a 1973.

41 Muzeum Klementa Gottwalda. Tematické okruhy sbírkotvorné činnosti Muzea Klementa Gottwalda $v$ oblasti dokumentace dějin revolučního dělnického hnutí a dějin Komunistické strany Československa. Praha, nedatováno; Muzeum Klementa Gottwalda. Katalog krátkých dokumentárních filmů. Praha: Muzeum Klementa Gottwalda v Praze, 1979. míra Iljiče Lenina $v$ Praze, vydalo i dvě knihy propagující muzeum. ${ }^{42}$ Určitou, současným termínem, VIP prezentací muzea byly dárkové předměty, ${ }^{43}$ výroční vyznamenání a udílení čestných uznání $\mathrm{k} 30$. výročí založení MKG, určené pro významné návštěvy a spolupracovníky (osoby i instituce). Jako pomůcka vedoucím stranických školení pro přípravu kolektivu pro návštěvy MKG a další přednáškovou činnost byly užívány soubory diapozitivů. Specifickým, ovšem zcela logickým, prostorem pro propagaci byla okna $v$ přízemí muzea. Kromě propagace výstav se zde prezentovaly např́klad i výsledky tematických soutěží pořádaných muzeem.

V dnešní době je hlavním médiem propagace kromě televize a rozhlasu především prostor internetu, zvláště sociální sítě, kde si sami jednotlivci předávají zajímavé odkazy a tipy. ${ }^{44}$ I zde je v př́padě akcí stále důležitou součástí jednoduchá vizualizace - pozvánka, stručná informace co, kde a kdy, jenž i svou grafickou podobou jednoznačně „prozradí“, o co se jedná. Tyto virtuální tiskoviny jsou také ale stále tišsěny, jako letáky pro umístění v prostorech výskytu potencionálních návštěvníků a ve větším formátu plakátů vyvěšovány na nástěnky a výlepové plochy ve veřejném i poloveřejném prostoru. Plakáty a propagační tiskoviny tak stále plní svou funkci i po desítkách let od svého vzniku, navíc v dalším

42 HRON, Pavel (ed.). 20 let Muzea V. I. Lenina $v$ Praze. Praha: Muzeum V. I. Lenina, 1973; JEŽEK, Alexandr a Milan PEREMSKÝ. Muzeum Vladimíra Iljiče Lenina v Praze. Praha: Středočeské nakladatelství a knihkupectví v Praze, 1976.

43 Jednalo se o drobnou sádrovou bustu K. Gottwalda v dárkové krabičce, dále medaile a plakety. MJF mělo vlastní pamětní medaili a skleněné těžítko s portrétem J. Fučíka.

44 K tématu např. Využití sociálních sítí v kulturních institucích: Případová studie online komunikace Muzea Karla Zemana. Muzeum: Muzejní a vlastivědná práce, 2015, roč. 53, č. 2, s. 54-58. ISSN 1803-0386. virtuálním formátu a v nových potenciálech. ${ }^{45}$

\section{Kulturní či politický plakát?}

Plakát je nejčastěji konfrontován $\mathrm{v}$ kontextu požadavků na umělecké dílo. V odborné literatuře a ve výstavních projektech byla již věnována velká pozornost především politickým, filmovým, divadelním či autorským plakátům. Řada muzeí a galerií prezentuje tematické kolekce plakátů ze svých sbírek $^{46}$ a jednotlivě se objeví i další témata. ${ }^{47}$ Výrazná je vlna výstav válečných plakátů, vycházející především $\mathrm{z}$ unikátních kolekcí jednotlivých muzeí a galerií, a také z trvalého zájmu o vojenskou historii. ${ }^{48}$ Základní výčet nesmí opomenout ani přehled vývoje plakátu, ${ }^{49}$ jenž kromě chronologického výkladu zahrnuje hodnocení, vývoj technik a okrajově proměny uplatnění plakátu ve veřejném prostoru.

Kritické hodnocení role, kvalit a hlavně vlivu plakátu, jako média,

45 Srov. NOGA, Pavel. Typografický plakát: tradiční komunikační médium v období rozvinutých digitálních technologií. 1. vyd. Brno: Masarykova univerzita, 2015. ISBN 978-80-210-8063-8; NOGA, Pavel. Design na cestě. Ostrava: Ostravská univerzita, 2014. ISBN 978-80-7464-133-6.

46 Např. katalogy věnované kolekcím na dané téma: katalogy Moravské galerie v Brně k přírůstkům, tematickým výstavám a bienále; MUZEUM ROMSKÉ KULTURY. Fond plakátu a pozvánek: (přirůstky 1991-2012): sbírky Muzea romské kultury. Brno: Muzeum romské kultury, 2014; Plakatausstellung aus den beständen des Museums für Deutsche Geschichte Berlin. Berlin, 1984; HORTON, Melanie. Empire Marketing Board posters. Manchester City Galleries. London: Scala, 2010. ISBN 978-1-85759-655-7.

47 Např. Veletržní a výstavní plakát: ze sbírek Moravské galerie v Brně a Uměleckoprůmyslového muzea v Praze: $v$ Brně, 1. ř́jina - 22. listopadu 1998. Brno: Moravská galerie, 1998. ISBN 80-7027-090-X.

48 Např. TÖRÖK, Jan a Adam HNOJIL. Válečné plakáty 1914-1918. Hluboká nad Vltavou: Alšova jihočeská galerie, 2017. ISBN 978-80-8779965-9; FINKOVÁ, Dagmar a Sylva PETROVÁ. The militant poster 1936-1985. Prague: International Organization of Journalists, 1986; ZEGERS, Peter a Douglas W. DRUICK (eds.). Windows on the War: Soviet TASS posters at home and abroad, 19411945. Chicago: The Art Institute of Chicago, 2011; Posters of the First World War. London: Imperial War Museum, 2014

49 Např. KROUTVOR, Josef. Poselství ulice: z dějin plakátu a proměn doby. Praha: Comet, 1991. 
se omezuje především na politickou propagandu - její výrazové prostředky, dopad na publikum a srovnání s vývojem ve východním a západním bloku. Nechybí umělecko-historické rozbory, zvláště u autorských, kulturních - převážně filmových a divadelních plakátů. Nelze vynechat teorii technik a vývoje plakátové tvorby, ${ }^{50}$ jenž je spíše učebnicí pro zájemce o grafický design.

Výběrem z typické každoroční produkce plakátů v šestnácti tematických skupinách v období od 1958 do devadesátých let jsou soupisy Česká grafika a mapy $v$ roce ..., které poskytují možnost určité představy o vývoji plakátů širší škály témat. ${ }^{51}$ Jedná se však o výběr, takže soupisy nelze použít při kvantitativním výzkumu. Důležité jsou však obrazové př́ilohy, i když jsou ještě zúženým výběrem z výběru. Důležitým zdrojem pro rozbor tištěné mediální tváře kulturních institucí a jejich činnosti je Bulletin Moravské galerie v Brně č. $72,{ }^{52}$ věnovaný teoretickým rozborům i vybraným př́kladi̊m vizuální identity muzeí (hlavně umění) a galerií. Až na jednotlivosti je však plakátová a obecně tištěná propagace muzeí stále nezmapovaným a informačně nevytěženým médiem.

Plakáty MKG, stejně jako ostatních stranických muzeí, nebyly ale pouhou reklamou na instituci a jeho činnost. Součástí poslání tohoto specializovaného muzea bylo především náležitě působit na co nejširší veřejnost propagandisticky. Angažované vizuální médium je originálním dokladem oficiálního chtění státního aparátu v oblasti

50 Uceleně např. HOLLIS, Richard. Stručná historie grafického designu. 1. vyd. Praha: Rubato, 2014 ISBN 978-80-87705-27-8.

51 Bibliografický katalog ČSR. České knihy, Česká grafika a mapy v roce ... Praha: Státní knihovna ČSSR - Národní knihovna, 1958-1998. ISSN 1210 9363.

52 Bulletin Moravské galerie v Brně č. 72. Brno: Moravská galerie v Brně, 2015. kultury a jednoho z jeho řízeného vlivu na masy Čechoslováků.

Zdenek Primus ve stati $O$ nevidění politického plakátu a apolitičnosti kulturního plakátu charakterizuje rozdílnost vnímání politických versus kulturních plakátů ve veřejném prostoru: „Jak známo, ulice byla pevně v rukou systému, náš chodec viděl jen více či méně dobrou inzerci na kulturní události města. Politické plakáty sice viděl také, ale jistě jim nevěnoval žádnou pozornost, proč také, každý: disident, Mitläufer, apolitický neználek, ale i angažovaný komunista věděl, $k$ čemu plakáty jsou. Jim všem bylo na jiném místě, především pak $v$ práci ř řčeno, kam maji $v$ ten který den jít a co tam mají dělat, což bylo národem poslušně prováděno. Politické plakáty fungovaly jen jako upomínka systému ve smyslu: 'Big Brother` is watching you. Měly tedy zastrašovací funkci a ne funkci informativní. Oproti tomu plakát upozorňující na kulturní nabídku kin, divadel a koncertních siní, abych jmenoval ty nejrenomovanějš́ $v$ pořádku stupně návštěvnosti, takový plakát byl-pomineme-li čistě typografické vyrozumění - zpravidla uměleckým angažmá autora." Mediální tvář MKG je ukázkovým prríkladem prolnutí oficiální politické a kulturní propagace. Sama instituce byla svým posláním politická. Stejně tak prezentace v expozicích a flexibilní lektorské výklady. Většina výstavních a kulturně vzdělávací projektů muzea byla svou náplní jasně politická, že i jejich reklamní kampaň byla politickou agitací a nejen poutačem kulturní akce. Prvotní účel pozvání na kulturní zážitek je vlastně jen zástěrkou pro politickou výchovu. Na první pohled je toto zřejmé i z vizuálu většiny plakátů a tisko-

53 PRIMUS, Zdenek. O nevidění politického plakátu a apolitičnosti kulturního plakátu. In Znameni doby = Signs of the times: sborník přednášek z mezinárodních sympozií Kultura, politika a společnost ve střední a východní Evropě 19452000: Moravská galerie v Brně 18.-19. 11. 1999, Manchester Metropolitan University 18. 3. 2000. Brno: Moravská galerie, 2003, s. 27. vin. Všudypř́tomná červená barva, revoluční symbolika, poučné texty, portréty vůdců, stylizované postavy $\mathrm{v}$ jasně určených emocích, hesla, to jsou prostředky používané $v$ tištěné reklamní kampani stranických muzeí, politicko-dokumentárních výstavách a akcích, vycházející z grafického a obsahového stylu oficiální názorné agitace. Do této charakteristiky plakáty MKG v obecné rovině jistě zapadají.

Samozřejmě se s propojením politického a kulturního obsahu na plakátech setkáváme již dříve, ale pro vymezené téma věnované instituci MKG je pro kvalitativní konfrontaci ukázkový plakát Výstavy revolučních bojů z roku 1949 od Jana Čumpelíka. ${ }^{54}$ Obraz dělníka odhodlaně směřujícího do revolučního boje, $s$ puškou a zataatou pěstí. $V$ pozadí stejně dominantní liniová postava husity. Sugestivní ztvárnění společenské změny po únoru 1948 je ukázkovým př́íkladem uměleckého díla s propagandistickým námětem ve službách mediální prezentace. ${ }^{55}$ Kvalitní autorská malba, doplněná textem, vytvořila jasně čitelnou a výraznou upoutávku, s níž se může zosobnit velké množství potencionálních návštěvníků. Zde jasně převažuje upoutání pozornosti výrazností motivu nad sděleními $\mathrm{v}$ textu. Motiv revolučnosti je vyjádřen emocí bezejmenného hrdiny a husitou jako odkazem na národní tradici boje. Není třeba prvoplánové symboliky komunistického hnutí, aby i bez rudé barvy a srpu s kladivem plakát doplnil samotný název výstavy o jasnou informaci o obsahu akce. Až neuveřitelně prostě je zde znázorněno chtění oficiálního státního aparátu o propojení současnosti s minulostí jednotou z davu vystoupivšího bezejmenného dělníka a řadového husitského

\footnotetext{
54 Jan Čumpelík (1895-1965), čelní představitel Armádního výtvarného studia.

55 Dělník, návrh na plakát Výstavy revolučních bojů, 1949, olej na plátně, rám dřevo s polychromií, $1700 \times 1410 \times 80$ mm. NM. SMDH. H11U-37. Plakát k výstavě vydal Melantrich, 1949.
} 


\section{MUSEUM KLEMENTA GOTTWALDA}

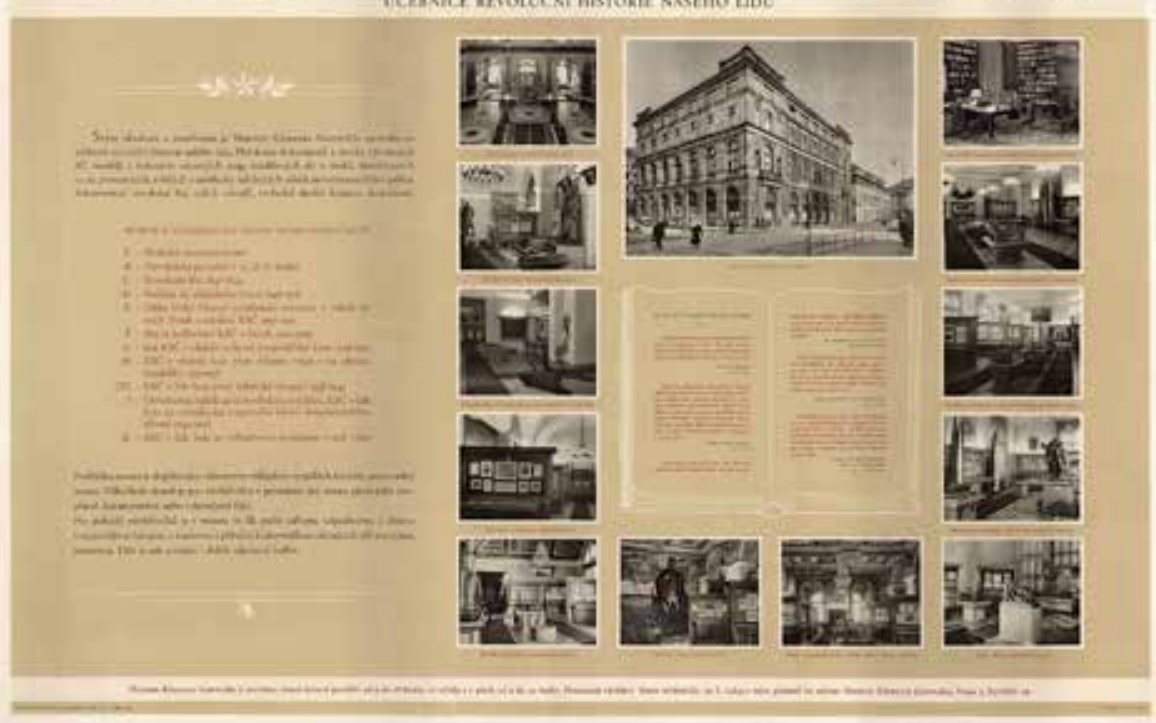

Obr. 3: Plakát Museum Klementa Gottwalda. Učebnice revoluční historie našeho lidu (autor neuveden, nakladatelství Orbis, 1955). Národní muzeum, Sbírka Muzea dělnického hnutí, H11P-91.

bojovníka, s nimiž se může většina pracujících ztotožnit. Nejen běžné zaujetí vizualitou barvy a textu, ale právě kompozice scény a výběr aktérů, oslovuje potencionální návštěvníky výstavy - masy pracujících. Plakát z produkce národního podniku pro průmysl grafický a nakladatelství Melantrich ${ }^{56}$ byl využit nejen pro kampaň ve veřejném prostoru, ale i na obálku 8. svazku Aktualit v obrazech. ${ }^{57}$ Dopad propagace volně prodejným tištěným médiem je zřejmý, když zjistíme, že jeho 6. svazek téhož roku byl věnován vítězství našich hokejistů na MS ve Stockholmu. V 70. a 80. letech je motiv Čumpelíkova dělníka použit na plakátech či předmětech k výročím LM. Bohužel, i když i v dalších letech vznikaly kvalitní autorské předlohy, většinou pro politické plakáty, tak MKG se tímto směrem nevydalo.

\footnotetext{
56 Dobový název viz Slovník české literatury po roce 1945 [online]. Praha: Ústav pro českou literaturu AV ČR [cit. 2019-08-29]. Dostupný z www: $<$ http://www.slovnikceskeliteratury.cz/showContent.jsp?docId $=1832 \&$ hl $=$ Melantrich $+>$.

57 Výstava dějin revolučních bojů. Praha: Svět v obrazech, 1949.
}

\section{Tváŕ MKG na plakátech}

Samotný název instituce proklamuje osobu - historickou postavu, která by tedy měla být její „tváří“. Ovšem původně Museum revolučního hnutí zůstalo, i po svém dedikování presidentu Gottwaldovi, muzeem dějin dělnického hnutí a KSČ. Postava dělnického presidenta byla spíše jen součástí prezentovaných témat, stejně jako jeho podobenka na plakátech, pokud tam vůbec byla.

Otevření MKG bylo, jako u ostatních stranických muzeí, provázeno rozsáhlou propagační kampaní, ale význam plakátu byl zřejmě $\mathrm{v}$ tomto případě podceněn. ${ }^{58}$ První dohledaný plakát muzea je až z následujícího roku 1955. Navíc plakát $M u-$ seum Klementa Gottwalda Učebnice revoluční historie našeho lidu (autor

\footnotetext{
58 V záznamech o činnosti MKG za konec 1954 a 1955 není ani zmínka o propagaci jinou formou než tiskem a audiovizuálními médii. NA v Praze. Fond 1065 - ÚD KSČ, kart. 114, a. j. 815. Stručná zpráva o činnosti MKG v Praze a jeho poboček v roce 1955, 17. 4. 1956. Srov. „K popularisaci musea [MVIL, roku 1953] bylo použito samozřejmě i běžných prostředků jako plakátů,....". NA v Praze. Fond 1065 - ÚD KSČ, kart. 114, a. j. 815. Zpráva o činnosti musea MVIL za rok 1953, s. 7.
}

neuveden, nakladatelství Orbis), je oproti charismatickým bojovníkům z plakátu Výstavy revolučních bojů skokem do popisného realismu fotografií a textů na neutrálně pojatém okrovém pozadí. ${ }^{59}$ Černobílým fotografiím ve čtvercové kompozici pravé části plochy dominuje záběr na budovu muzea, ostatních 12 záběrů ukazuje interiér (sály expozice, dvoranu a pracovnu K. Gottwalda). Mezi fotografiemi je $v$ kresbě bílou barvou provedena otevřená kniha, na jejíchž listech jsou citace $\mathrm{z}$ návštěvní knihy. Text $\mathrm{v}$ levé části plakátu obsahuje informace o muzeu včetně detailů o počtech sálů, přes rozpis jednotlivých částí expozice až po zázemí pro návštěvníky (odpočívárna, čítárna, studovna a „dobře zásobený bufet“60). Nad a pod textem jsou ozdobné lišty lipových ratolestí, nahoře s pěticípou hvězdou. U horního okraje plakátu je pás s názvem muzea včetně podtitulu UČEBNICE REVOLUČNÍ HISTORIE NAŠEHO LIDU. V úzkém pásu na spodní části jsou údaje o otevírací době a kontakty.

Naopak v případě první pobočky MKG byl plakát vydán již v roce otevření expozice (1953). Plakát v české a slovenské verzi Muzeum počátků čs. dělnického hnutí od Jaroslava Kaisera a Jindřicha Koukolského vydaného nakladatelstvím Svoboda je založen na tvářích vůdců provedením kvalitních portrétů. ${ }^{61}$ Na bíle lemované červené ploše jsou v oválných bílých orámováních s uvedením jmen prezentováni Josef Hybeš, Ladislav Zápotocký a Josef Boleslav Pecka. Při horním okraji je zlatě psáno PROLETÁŘI VŠECH ZEMÍ SPOJTE SE a na spodním okraji je černě uvedena otevírací doba. V roce 1957 se plakátová prezentace břevnovské pobočky posunula od podobenek vůdců

\footnotetext{
59 NM. SMDH. H11P-91.

60 Tamtéž.

61 Múzeum počiatkov čs. robotníckeho hnutia. Praha - Břevnov. 1953; NM. SMDH. H11P-309; Muzeum počátků čs. dělnického hnutí. Praha Břevnov. 1953; NM. SMDH. H11P-310.
} 
sociální demokracie k vizuáliím budovy a expozice dle vzoru MKG. Plakát Museum počátků čs. dělnického hnutí (autor neuveden, nakladatelství Orbis) má na ploše bíle orámovanou oranžově tónovanou fotografii budovy U Kaštanu. Pravou část zaplňuje šest fotografií budovy a náhledů do expozic. Fotografie pamětní síně v levé spodní části je zvýrazněna bordurou. Název muzea je při horním okraji a adresa s kontakty a otevírací dobou jsou při okraji spodním, vše tmavě červeným písmem. Vliv MKG na plakátovou propagaci muzea v Břevnově tímto posunem od osobností $\mathrm{k}$ budově vlastně skončil.

Srovnáme-li MKG s prvním ústředním stranickým muzeem, tak v MVIL byla již v roce otevření expozic (1953) na poradách plánována v rámci propagace (reportáže v tisku a ve filmových týdenících) letáková a plakátová kampaň v Praze letáky do tramvají a trolejbusů, plakáty též do významných krajských měst. ${ }^{62}$ Pod citátem J. V. Stalina MĚJTE V PAMĚTI, MILUJTE, STUDUJTE ILJIČE, NAŠEHO UČITELE - NAŠEHO VÜDCE se skrývá plakát MVIL, vydaný bez uvedení autora roku 1954, dle provedení pravděpodobně také v nakladatelství Orbis. ${ }^{63} \mathrm{O}$ polovinu menším a bílým, tedy ne tak výrazným, písmem psaný citát K. Gottwalda AŤ JE MUSEUM V. I. LENINA ŠKOLOU KOMUNISMU PRO MILIONY NAŠICH LIDÍ dělí horizontálně plochu i dvě řady fotografií. V horní je na největším centrálním snímku portrét V. I. Lenina, „překvapivě“ stejný jako na obou plakátech z následujícího roku. Vpravo od tohoto snímku je K. Gottwald při otevírání MVIL v lednu 1953.

62 NA v Praze. Fond 1065 - ÚD KSČ, kart. 114, a. j. 815. Návrh opatření k zajištění návštěvnosti MVIL, 13. 5. 1953, s. 2.

63 Autorka plakát zná pouze z evidenčního lístku s fotografií z tematického katalogu plakátů MKG. Bohužel fotografie nezachycuje spodní okraj s tiráží a je černobílá, takže nelze uvést barvy. Dle provedení grafiky obdobně jako MKG a následného plakát MVIL z 1955 je pravděpodobné, že se jedná o produkt Orbisu.
Ostatní fotografie v horní linii jsou pohledem do expozic. Snímky ve spodní linii reprezentují dění v muzeu (návštěvníky, doprovodné akce). Stejně jako na plakátu MKG, i zde jsou citace z návštěvní knihy. U spodního okraje je otevírací doba a zřejmě i kontakty. V roce 1955 vznikly hned dva plakáty MVIL. Nejprve to byl vizuálem obdobný typ od stejných autorů Jaroslava Kaisera a Jindřicha Koukolského jako první plakát pro Břevnov Museum V. I. Lenina, nakladatel není uveden. ${ }^{64}$ Červené ploše $s$ bílým orámováním dominuje barevný portrét V. I. Lenina a ve spodní části kresba sídla muzea, Lidového domu. Mezi nimi je v černém a bílém písmu název instituce a adresa, u spodního okraje je černým písmem otevírací doba. $\mathrm{V}$ prosinci byl nakladatelstvím Orbis vydán plakát Museum Vladimíra Iljiče Lenina $v$ Praze od Stanislava Kováře ${ }^{65} \mathrm{Na}$ okrové ploše oddělené bordurou od bílého okraje je kombinace černobílých fotografií interiéru muzea, černobílého portrétu V. I. Lenina, kresby sídla muzea a textu - s popisy fotografií a citátem A. Zápotockého.

U dvojice porovnaných stranických muzeí se $\mathrm{v}$ počátcích jejich existence, tj. v 50. letech, vykrystalizoval typ plakátu vizuálně zpracovaného dle vzorů nástěnkových propagačních tiskovin, tvořených $\mathrm{k}$ výchově nového socialistického člověka. Založený byl na textovém výkladu a fotografiích. Do jaké míry je to dáno společným zpracovatelem ORBIS (státní nakladatelství zaměřené na propagaci státu, popularizaci vědy a umění a literaturu faktu $^{66}$ ), je na další prohloubený výzkum, podložený poznáním autorských týmů a vnitřních regulí

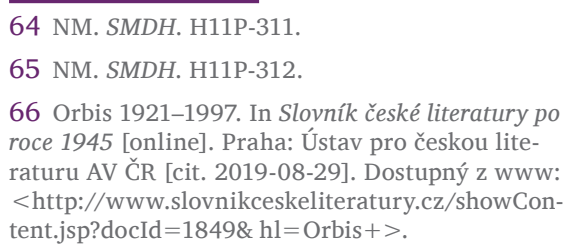

nakladatelství. Pro příklad k porovnání lze uvést obdobné vizuály základních plakátových produktů Orbisu - edice Nástěnka a plakáty k osobnostem. Dále stejný koncept Orbisu založený na fotografiích, kresbě budovy muzea a celkem rozsáhlém textu prezentuje plakát Národního technického muzea $\mathrm{z}$ roku 1955 od J. Havlína, ${ }^{67}$ jenž je místo ratolestí a hvězd dozdoben kresbami dopravních prostředků. Vliv na vizuál plakátů jistě mělo i společné vedení Odborem muzeí a výstav ÚD KSČ. Ovšem z doposud poznaného mechanismu řízení obou muzeí šlo spíše o otázky financí a právě volby zpracovatele, tedy nakladatelství.

MKG se v prvním desetiletí své existence propaguje jako „učebnice dějin revolučních bojü“ čemuž odpovídá i plakát kombinující realismus fotografií s výčtem obsahu expozic a „glorizujícími doplňky ratolestí, hvězd“. Podobné neohistorizující tvarosloví odpovídá i ideám z dob př́prav otevření MKG. Při realizaci první expozice byla jejich důležitou součástí neorenesanční výzdoba sálů, která navíc byla doplněna novou výzdobou budovy s motivy socialistické doby - např. zlatem zářící výjevy pracujících a dětí od Vojtěcha Tittelbacha (1954).

Po vydání plakátu v roce 1955 se pro celých šestnáct let nepodařilo dohledat nové plakáty MKG, kromě výstavních. ${ }^{68}$ Jedním z možných důvodů mohlo být, že od konce 50. a na počátku 60 . let se aktivity muzea točily kromě lektorské práce především kolem reinstalací expozice a vydávání průvodců $\mathrm{k}$ nim.

V období, kdy probíhala rekonstrukce budovy, byly expozice MKG

67 Zřejmě Jiřího Havlína.

68 Ve fondu Plakáty SMDH ještě není roztříděna část s nejstaršími kusy (do roku 1945), která je na sterilizaci, ale zde se plakáty MKG nepředpokládají. V zachovaných letech chronologického katalogu plakátů MKG (necelé 1959, 1962 a 1964 celé 1960, 1961, 1965-67) ani v tematickém pod heslem $K$. Gottwald (muzea tam nejsou nebo se nedochovala) nejsou plakáty MKG, přestože běžně tam jsou plakáty výstav i plakát z roku 1972. 
uzavřené a konaly se zde „jen“ výstavy, vznikl roku 1972 plakát $M U$ SEUM KLEMENTA GOTTWALDA od autorů Jaroslava Kaisera a Oldřicha Jirky. ${ }^{69}$ Středovou dominantou je červený prapor s názvem muzea a dvojice stužek, na horní je nápis „PROLETÁŘI VŠECH ZEMÍ SPOJTE SE“. Ve spodní části jsou Hradčany, od nichž na celou plochu plakátu přechází stylizované nebe. U spodního okraje je červeně psána adresa. Plakát se ve sbírce MKG také dochoval na desce a nad ním je dolepen pás s otevírací dobou, byl tak zřejmě užíván přímo před muzeem jako poutač.

Rokem 1974 se znovu otevírají expozice MKG a při této př́ležitosti vychází dvojice plakátů bez uvedení autora z produkce Rudého práva. Plakátu MUZEUM KLEMENTA GOTTWALDA NOVĚ INSTALOVANÉ EXPOZICE REVOLUČNÍHO DĚLNICKÉHO HNUTÍ A KSČ dominuje sestava červených praporů a zlatě zbarveného srpu a kladiva, vše na světle okrové ploše. Pod hlavním nápisem je uvedena adresa a otevírací doba. ${ }^{70}$ Druhý plakát MUZEUM KLEMENTA GOTTWALDA EXPOZICE REVOLUČNÍHO DĚLNICKÉHO HNUTÍ A KSČ je oproti výše popsanému, kde vizuál tvoří symboly bez konkrétní informační náplně, návratem $\mathrm{k}$ realismu 50 . let a zároveň použitým typem dokumentárních fotografií vlastně prvním produktem plakátové propagace MKG v normalizačním stylu - návratu k poúnorovým tradicím a akcentaci díla Gottwalda a Lenina. ${ }^{71} \mathrm{Na}$ první pohled červenou plochou výrazný plakát se zlatým a bílým názvem, adresou a otevírací dobou je poset mozaikou zlatě vystínovaných fotografií ze stávek, osvobození, Gottwalda při projevu, sjezdů, průmyslu a titulních stran Rudého práva, kde samozřejmě nechybí Gustáv Husák.

69 NM. SMDH. H11P-298/1, H11P-298/2 (na desce).

70 NM. SMDH. H11P-314.

71 NM. SMDH. H11P-315.

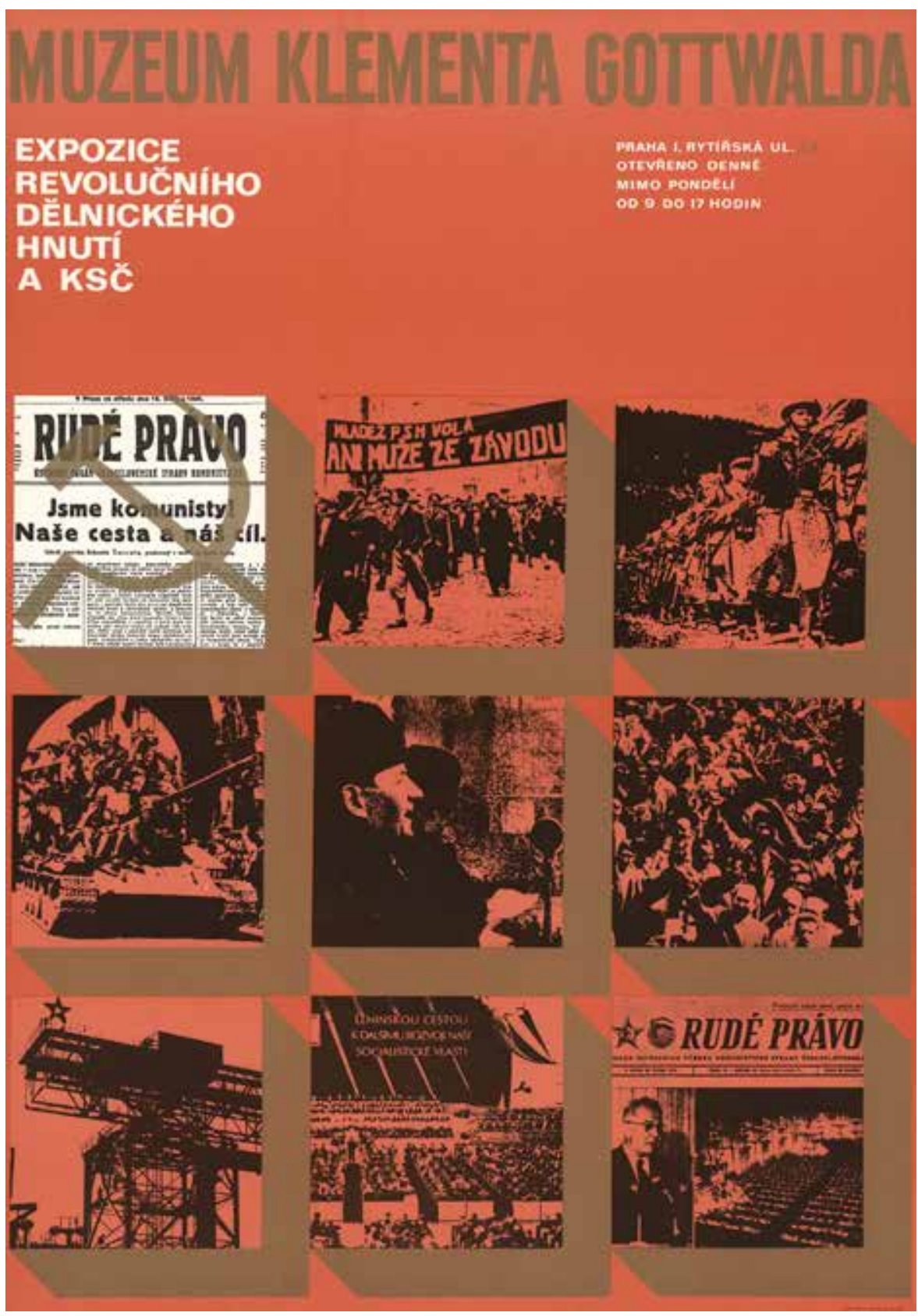

Obr. 4: Plakát Muzeum Klementa Gottwalda. Expozice revolučního dělnického hnutí a KSČ (autor neuveden, nakladatelství Rudé právo, 1974). Národní muzeum, Sbírka Muzea dělnického hnutí, H11P-315.

Ze symbolů je zde použit srp a kladivo ve zlaté barvě, ovšem $v$ nevýrazném umístění na jedné z fotografií. Přímo k otevření existuje strohý typoplakát SLAVNOSTNÍ OTEVŘENÍ NOVÉ EXPOZICE MKG

30. 4. 1974, kde černý nápis na červené ploše akcentuje bíle lemovaná pěticípá hvězdička téměř ve středu plochy. ${ }^{72}$ Dle jednoduchosti prove-

72 NM. SMDH. H11P-287. dení bez jakékoliv tiráže se pravděpodobně jedná o výtvor provozu muzea, konkrétně výtvarníka, který byl dle zpráv o činnosti součástí pracovního týmu.

K výročí založení muzea $\mathrm{v}$ roce 1979 byl vydán plakát 25 let Muzea Klementa Gottwalda od Karla Kroupy, kterému dominuje v celé horní polovině hnědé „25MKG“, doplněné v pravém horním rohu červenou 
pěticípou hvězdou. ${ }^{73}$ Ve spodní části, oddělené nápisem $s$ názvem plakátu, je stylizovaná vavřínová ratolest s listy z dokumentárních fotografií (K. Gottwald, G. Husák a L. I. Brežněv, demonstrace, Rudé právo ad.). Na spodním okraji je STÁLÁ EXPOZICE DĚJIN REVOLUČNÍHO DĚLNICKÉHO HNUTÍ A KSČ, otevírací doba a kontakty. Plocha je světle okrová. K tomuto výročí vydalo muzeum i brožuru, kde byl použit stejný font písma pro „25MKG“ na obálce jako na plakátu. Následně se stejná podoba názvu MKG průběžně objevuje na tiskovinách i v 80. letech. Ke stejnému výročí vydalo svůj plakát i MVIL, jenž si stále drželo nastavený styl své vizuální prezentace - Lenina a Lidový dům. Popředí bílé plochy dominuje černobílá fotografie busty V. I. Lenina od Karla Čermáka, která byla součástí instalace v předsálí Leninovy síně. V pozadí spodní části je světle žlutě tónovaná fotografie Lidového domu s červenými prapory. Horní část zaplňuje do praporu stylizovaná červená plocha s nápisem 25. VÝROČÍ OTEVŘENÍ MUZEA V. I. LENINA V PRAZE 1953-1978. ${ }^{74}$ V porovnání s tímto plakátem a v kontextu svých tištěných propagačních materiálů, MKG opustilo jednostrannou orientaci svého vizuálu na zobrazení budovy. Na výročním plakátu se vůbec neobjevila a poprvé je zde zobrazen Gottwald, i když jen jakoby náhodou na jedné z osmi dokumentárních fotografií a v jasně čitelném kontextu proklamace normalizačního režimu o návratu k odkazu prvního dělnického prezidenta (fotografie prezidenta Husáka s L. I. Brežněvem tvoří vrchol ratolesti).

V 80. letech se objevuje jak návrat k „přetextování“ 50. let, tak zároveň navázání na zakomponování fotografie Gottwalda do vizuálu plakátu na konci let sedmdesátých. V červenci 1984 byly v nakladatel-

73 NM. SMDH. H11P-291.

74 NM. Sbírka novodobých českých dějin (dále SNČD), fond Plakáty, b. č.

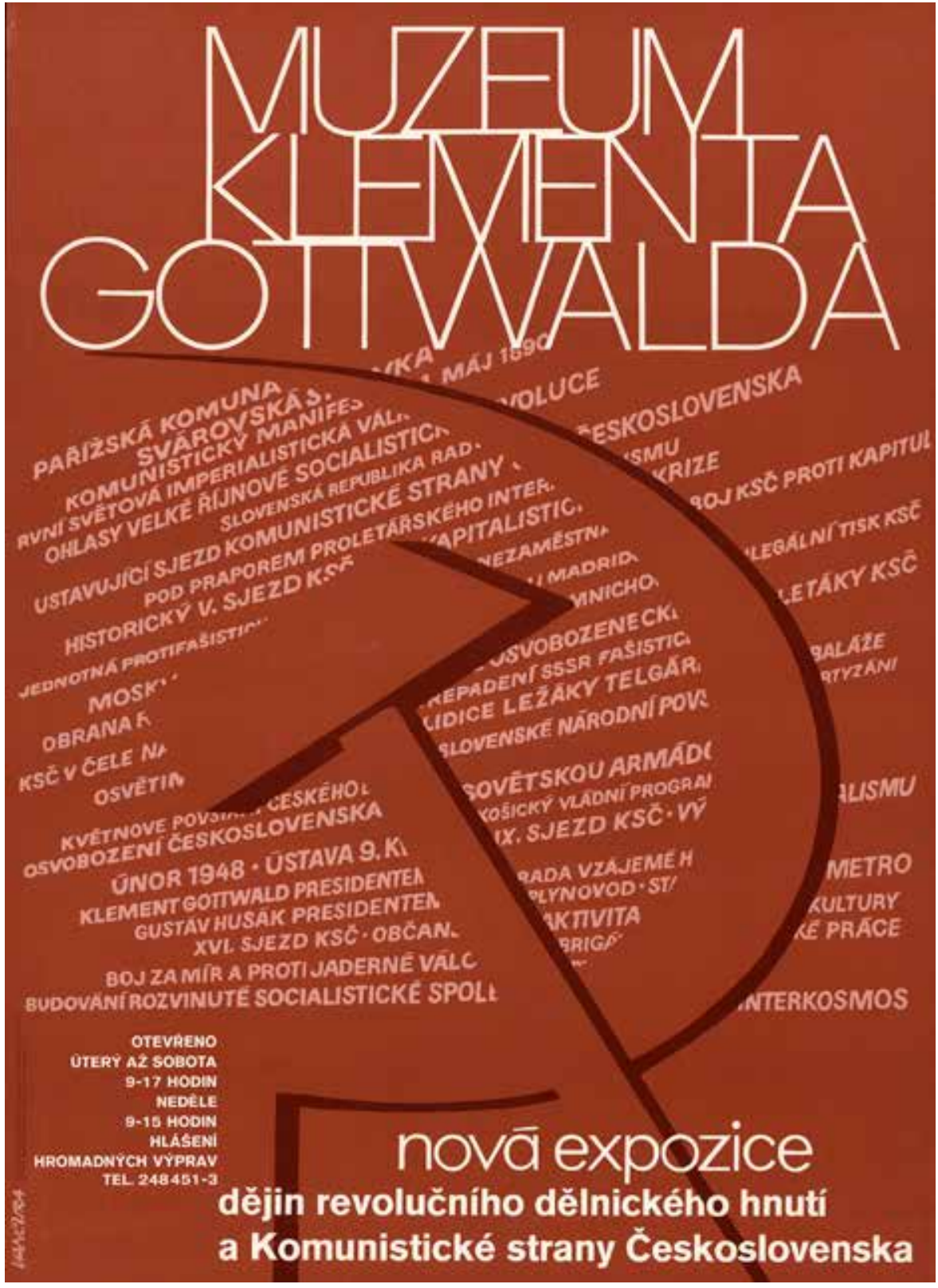

Obr. 5: Plakát Muzeum Klementa Gottwalda. Nová expozice dějin revolučního dělnického hnutí a Komunistické strany Československa (autor Bohumil Vančura, nakladatelství Svoboda, 1984). Národní muzeum, Sbírka Muzea dělnického hnutí, H11P-297.

ství Svoboda vydány dva plakáty. MUZEUM KLEMENTA GOTTWAL$D A$, nositel Řádu Vítězného února od Jiřího Kodejše vyšel v edici Doba a osobnost a rozsahem textu se blíží spíše letáku. ${ }^{75}$ Bílé ploše dominuje červeně zabarvená stylizovaná vlajka složená z fotografií (K. Gottwald, demonstrace, V. Remek s A. A. Gubarevem) a textu o muzeu od Libuše Eliášové. Zlatou

75 NM. SMDH. H11P-296. barvou je v pravé horní části monogram KG a v levém spodním rohu citát G. Husáka. U horního okraje je červeně psaný název muzea a před ním červená pěticípá hvězdička. Plakát MUZEUM KLEMENTA GOTTWALDA nová expozice dějin revolučního dělnického hnutí a Komunistické strany Československa od Bohumila Vančury má červenohnědou barvu s bílým textem (viz název plakátu a otevírací doba). Střední části dominuje srp 
a kladivo s vystínováním, za ním je plocha s heslovitými nápisy témat prezentovaných v MKG. ${ }^{76}$ Oproti tomu MVIL vydalo roku 1987 umělecky mnohem odvážnější plakát Muzeum V. I. Lenina. Znovuotevření stálé expozice, signováno R. Vaněk. ${ }^{77}$ Červené ploše dominuje nově pojatý portrét Lenina hledícího na „koláž socialismu“ (srp a kladivo s obřím obilím, paneláky, továrna, raketou nesená pěticípá hvězda ad.). V horní části u názvu a adresy muzea je již tradičně zobrazení budovy. Ve spodním pravém rohu návštěvní doba.

Kvalitativním protipólem Vaňkova plakátu s Leninem ze stejného roku je „realistický“ plakát Muzeum Julia Fučíka. Otevřeno $k$ 85. výroči narození hrdiny československého lidu jako pobočka $M K G .{ }^{78}$ Bílé ploše dominuje fotografie usmívajícího se Julia Fučíka v červeném orámování, pod ní je červeně název muzea a pěticípá hvězda. ${ }^{79}$ Dovětek, kontakty a návštěvní doba jsou psány černě ve spodní části. Vydalo Nakladatelství Svoboda, autor není uveden. Plakát s jasnou orientací vizuálu na osobu prezentovanou muzeem, jako by tím ani nepatřil do propagace MKG. I když určitá snaha o vysvětlující text tu také je. Stejně tak i použití orámované fotografie hrdiny a pěticípé hvězdy nás vrací $\mathrm{k}$ MKG a otázce kulturní nebo politický plakát? Pozvánka do muzea je skryta pod vizuálem štastného muže a rétorikou o hrdinství v doprovodu červené pěticípé hvězdy, tak jak je známe z politických plakátů. Tento poslední, a jako propagace nové pobočky jistě i významný plakát MKG, bohužel až na zpodobnění osobnosti, po níž je muzeum nazváno, nevybočuje

\footnotetext{
76 NM. SMDH. H11P-297.

77 Dle kvality provedení pravděpodobně Rostislav Vaněk.

78 NM. SMDH. H11P-125. Plakát byl vydán v roce 1987, ale muzeum bylo otevřeno v roce 1988.

79 Stejná fotografie byla předlohou pro kresbu portrétu Julia Fučíka na plakátě k výročí jeho narození. Julius Fučík 23. 2. 1903, autor: Zd. Zálešák, 1973. NM. SMDH. b. č.
}

z nastaveného standardu. Bohužel i svým kvalitativním provedením odpovídá spíše typoplakátům $\mathrm{k}$ výstavám spolupořádaným MKG v regionech. Pozitivním prvkem na plakátu Fučíkova muzea je nepoužití jeho ikonického portrétu, ${ }^{80}$ který se dostal až na keramické kachle. Nelze si proto odpustit ještě alespoň jeden příklad pro srovnání ústř̌ední muzejní instituce, srovnatelné prostředky pro propagaci, otevření expozice moderních dějin, rok 1986. Plakát Národního muzea Expozice českých dějin 19. a 20. století, vydalo Výstavnictví n. p. bez uvedení autora. ${ }^{81}$ Stříbrná plocha je osazena pouze písmem - název expozice je rozčleněn do malých písmen latinky, zdobně provedené „XIX“, modrého „a“ a červené „20“. Při horním okraji je oproti dominantnímu názvu zanikající jméno muzea, doplněné o „nositel Řádu republiky" a otevírací dobu. Až možná povrchně koncipovaný typoplakát diváka nezatěžuje př́ímou propagací náplně expozice, spoléhá na výpovědní hodnotu názvu. $\mathrm{Na}$ diváka nesměřuje diktované emoce jako fotografie novináře Fučíka, ale spoléhá na jeho vlastní zvědavost po zhlédnutí kontrastu přehnanosti 19. a barevné modernosti 20. století.

MKG bylo propagováno jako významné místo $\mathrm{v}$ kontextu kulturních památek i dokladů rozvoje socialismu, jak je zřejmé z řady propagačních materiálů (televizních pořadů, tisku). Dokládá to i mapa Prahy v prŕloze článku z roku 1954 Vyrostla nám nová Praha, kde jsou mezi počty nových domů, škol, tras dopravy, rozšsiřrení ZOO, Stalinova pomníku, MVIL i pobočka MKG v Břevnově. MKG tam není jen proto, že expozice ještě nebyly otevřeny. ${ }^{82}$ Zvláštní význam pro propagaci MKG v rámci šance nalákat velké

\footnotetext{
80 ŠVABINSKÝ, Max. Julius Fučík. 1950. Kresba uhlem na papíře. Národní galerie Praha. 81 NM. SNČD, b. č.

82 Vyrostla nám nová Praha. Svět práce, 8. 4. 1954.
}

počty návštěvníků z celé republiky měl plakát vydaný u př́ležitosti Spartakiády v roce 1980 - Vítáme Vás $v$ Praze od Jaroslava Vildta. ${ }^{83}$ Barevný ilustrovaný plán Prahy $s$ vyznačením kulturně historických památek a tras metra, kde je kromě MKG i Lidový dům $s$ popiskem MVIL a dům U Kaštanu s popiskem Muzeum počátků čs. dělnického hnutíi ${ }^{84}$ měl nabídnout kulturní vyžití účastníkům spartakiády.

Stranická muzea, spravovaná orgány KSČ, se ze sítě specializovaných a vlastivědných muzeí, vedených ministerstvem a regionální správou, spíše vyčleňovala. Přesto v roce 1985 se dvojice stranických muzeí - MKG a Muzeum revolučního dělnického hnutí jižních Čech (dále MDRH) stala náplní plakátu 18. květen Mezinárodní den muzeí, autorů Antonína Kalcovského (výtvarný návrh) a J. Langra (text), vydalo nakladatelství Svoboda. ${ }^{85}$ Doprovodný text: „Muzea a galerie $v$ [ČSR - zkráceno autorkou] patř́ $k$ těm kulturním zařizením, jejichž kulturně výchovná a vzdělávací činnost se významně podílí na utváření vědomí občanů v duchu socialistického vlastenectví, internacionalismu, solidarity s národy, bojujícími za národní osvobození, a boje za život $v$ míru." jako by byl překopírován z nástěnkových př́iloh Názorné agitace. Čtveřice barevných fotografií prezentuje jak jinak než budovu MKG a její expozici s bustou J. Fučíka, moderní budovu budějovického muzea a jeho expozici s bustami K. Marxe a B. Engelse. Na tmavém červenohnědém pozadí je text a doplňující linky v bílé a žluté barvě. Pro usazení do kontextu celostátní propagace tématu oslav muzeí je třeba alespoň drobné srovnání. Týden museí 24.-31. května 1959 vydaný Orbisem bez uvedení autora, je založen na výraznosti tmavého

\footnotetext{
83 NM. SMDH. H11P-265.

$84 \mathrm{~V}$ této době již pro zde umístěnou expozici nebyl původní název užíván. 85 NM. SMDH. H11P-313.
} 


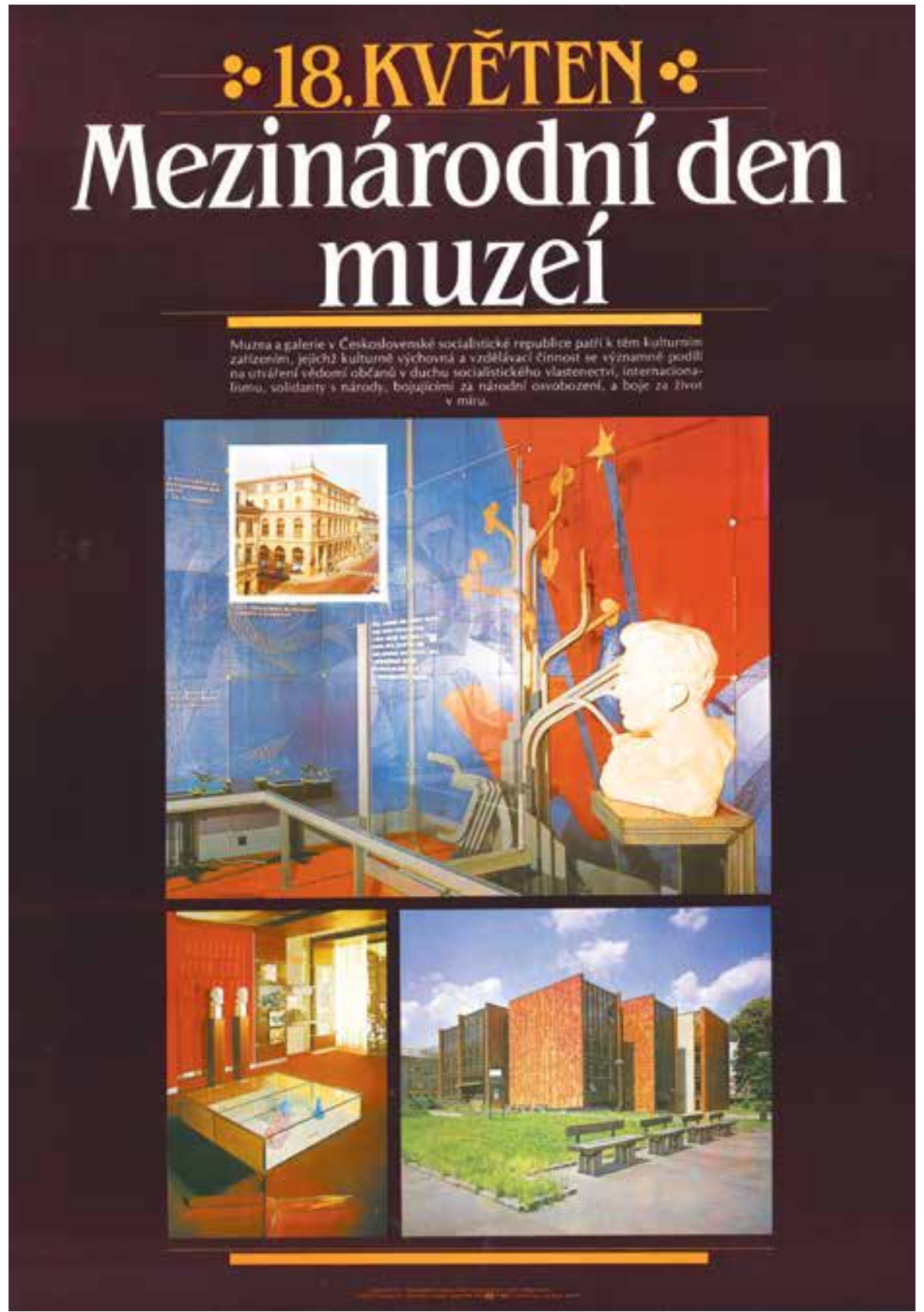

Obr. 6: Plakát 18. květen Mezinárodní den muzeí (výtvarný návrh Antonín Kalcovský, text J. Langr, nakladatelství Svoboda, 1985). Národní muzeum, Sbírka Muzea dělnického hnutí, H11P-313.

šestiúhelníku posazeného na orámovanou světlou plochu a doplnění textem: „musea dokumentují socialistickou výstavbu“. ${ }^{86}$ Což odráží dobový ideový požadavek na dovršení budování socialismu. Na plakátu TÝDEN MUZEÍ A PAMÁTKOVÉ PÉČE 29. IV.-4. VI. 1961 od Františka Kopence, vydaný v Orbisu roku 1961, je zřejmý vliv ideového tlaku

86 NM. SNČD, b. č. na modernizaci muzejních expozic v období 50. a počátku 60 . let. ${ }^{87}$ Žlutozelené ploše dominuje pochodeň s červenou hvězdou, po levé straně je fotografie expozice $M_{K G}{ }^{88}$ a vpravo veduta Prahy. Žlutý nápis je ve spodní části, datum v bílém písmu je pod plamenem pochod-

87 NM. SMDH, b. ̌̌.

88 Závěrečný sál expozice na téma $K S C ̌$ v boji za vybudování socialismu v naší vlasti. ně. Plakát 18. květen Mezinárodní den muzeí od Jana Jiskry (grafický návrh) a Jiřího Špéta (text) z roku 1987, z nakladatelství Svoboda, vlastně $\mathrm{i}$ přes uvedení autora textu kromě názvu nic dalšího textem nesděluje. Jeho vizuál je založen na působení barevné fotografie s detailem dřevěných konstrukcí kolny. ${ }^{89}$ Mezi vybranými plakáty je ten z roku 1985, místo připomenutí významu data, cílen na politicko-výchovné působení a propagaci konkrétních muzejních institucí. I plakát z roku 1961 má jen obecnou rovinu propagace tématu budování socialismu bez přímé reklamy na stranická muzea. I zde se tedy v souvislosti se stranickými muzei objevuje přesah jinak kulturního plakátu do propagandy plakátu politického.

\section{Závěr}

Zástupci veřejných organizací: „,... museum by mělo mít plakát ve všech poradnách a studovnách [marxismu-leninismu - dopl. autorky]" kontra zástupci vedení muzea „... zajištění návštěv musea různých běhů školení propagandistů a politických škol je úkolem především strany."

V duchu plánování, jednání (se zástupci organizací, ČTK, Krátkého filmu, ministerstev školství a zahraničí ad.), čekání na schválení návrhů a urychlených zpracování podkladů probíhala řízená propagace obou ústředních stranických muzeí podle zachované agendy jejich vedení a ÚD KSČ od jejich založení až do transformace ústavu na přelomu 60 . a 70 . let. $V$ praxi muzea připravovala podklady pro tištěnou propagaci a nad rámec přímo jednala s osobami organizující zájezdy skupin, předávala pravidelné informace ČTK a zajištovala focení a zprávy $\mathrm{z}$ akcí. Do jaké míry pracovníci muzea a jeho

89 NM. SMDH. H11P-207.

90 NA v Praze. Fond 1065 - ÚD KSČ, kart. 114, a. j. 815. Zápis z porady o propagaci a zvýšení návštěvnosti MVIL, konané dne 3. 9. 1953, s. 3. 
vedení určovali grafickou podobu tištěných materiálů nelze zatím hodnověrně specifikovat. $Z$ korespondence ústavu a vedení MKG je zřejmé, že probíhalo určité „připomínkování" provozních i metodických materiálů, ale propagace se týkají jen okrajově. U konkrétních produktů $\mathrm{k}$ propagaci se objevují jen záznamy o př́ípravě či vydání. ${ }^{91}$ V kontextu celkové propagace MKG vlastně ani malý počet vydaných plakátů $\mathrm{k}$ popularizaci instituce není nic nečekaného. Muzeum každý rok realizovalo průměrně dvě výstavy, jejichž plakáty zároveň veřejnosti připomínaly jeho existenci. I když pouze názvem.

Hlavní symbol užívaný ve spojitosti se stranickými organizacemi - červená pěticípá hvězda, je na plakátech MKG jako instituce opravdu př́tomna, ale výrazně v doplňkové pozici. Malé hvězdy jsou připojeny u názvu, ale až na v podstatě amatérský plakát $\mathrm{k}$ otevření nové expozice v roce 1974 nijak dominantně nevystupují. Ovšem druhý symbol srp a kladivo, se kromě reprodukce dokumentu v koláži plakátu z roku 1979, objevuje pouze na plakátě $\mathrm{k}$ nově instalované expozici $v$ roce 1974 a pak v roce 1984. Zde však zcela dominuje celkovému vizuálu. Na plakátu z roku 1972 není dokonce žádný z očekávaných symbolů použit, jejich roli převzal rudý prapor, který v množném provedení doplňuje srp a kladivo na plakátě z roku 1974. Pobočka MKG v Břevnově nemá na svých plakátech ani hvězdu, ani srp s kladivem. Stejně překvapivě malou roli jako $\mathrm{v}$ př́ípadě MKG plní hvězda na plakátech MVIL - drobné hvězdy spíše dekorují dva z trojice plakátů padesátých let. Naopak hvězdu jako výrazný prvek, díky změně barevnosti na žlutou, použil Rostislav Vaněk v roce 1987, ovšem ta nějak svou vícevýznamovostí nezapadá do klasické linie stranické propagace.

91 Souhrnné informace o vydaných tiskovinách jsou součástí každoročních zpráv o činnosti MVIL a MKG, ale nejsou bohužel vždy konkrétní.
Celkem překvapivě tedy plakáty, prezentující ústřední stranická muzea, nejsou ukázkovým př́kladem nadměrného užití této symboliky. Ukázkovým plakátem, kde tvarové stranické symboly zastupuje červená plocha, je plakát regionálního Muzea dělnického hnutí Brněnska od Jana Rajlicha staršího, z roku 1958 - autorské zpracování jasně na první pohled pochopitelné pozvánky do stranického muzea. ${ }^{92}$ Zde jsou prvoplánové symboly nahrazeny plastikou dělníků na červené ploše a výrazným názvem.

Kdo by ve vizuálu celkové propagace MKG čekal Klementa Gottwalda, tak se dočká až v polovině 70 . let. Předtím byla nejvíce prezentovaným symbolem instituce budova muzea, zvláště její fotografie. ${ }^{93}$ Budova a portrét K. Gottwalda se potkaly jen na brožuře k expozici otevřené roku 1974. Dále se budova neobjevuje ani na poslední brožuře, ani na plakátech. Výtvarně zpracované podobizny prezidenta Gottwalda dominují obálkám dvojice posledních brožur o MKG. ${ }^{94}$ Naopak na plakátech muzea se objevily jen dokumentární fotografie s prezidentem, v roce 1979 a vždy na jednom z roku 1974 a 1984. Srovnáme-li to s MVIL, kde je zobrazení V. I. Lenina na všech plakátech muzea a téměř na všech publikacích a brožurách, tak je jasně zřejmý rozdíl v pojetí prezentace osobností $\mathrm{v}$ obou muzeích. V případě MVIL je sice Lidový dům taktéž nepřehléd-

\section{Moravská galerie v Brně. Sbírka Grafický design, inv. č. 14891.}

93 Zobrazování a prezentace budovy v propagaci muzeí je celkem tradiční. Např. NM mělo na plakátech instituce a především na programových plakátech historickou budovu na Václavském náměstí. V roce 1975 založené MDRH v Českých Budějovicích má také na svém prvním plakátě zobrazeno své sídlo (Jihočeské muzeum v Českých Budějovicích. Fond bývalého MDRH, inv. č. Spl 3 398)

94 Muzeum Klementa Gottwalda v Praze. Expozice dějin revolučního dělnického hnutí a Komunistické strany Československa. Praha: ORBIS, nedatováno [po 1974]; Muzeum Klementa Gottwalda $v$ Praze. Expozice dějin revolučního dělnického hnutí a Komu nistické strany Československa - průvodce. Praha: Panorama, 1982. nutelnou součástí propagace, ale tvář V. I. Lenina převažuje a často jsou na tištěné propagaci současně. Dle moskevského vzoru vybudované MVIL mělo v Československu trvale udržet odkaz V. I. Lenina a jeho pobytu v Praze. Bylo to opravdu muzeum o jednom muži a jeho díle. Naopak MKG získalo svůj název náhle, nekoncepčně, kvůli potřebě uspokojení piety v období smutku po náhlé smrti prvního dělnického presidenta. Nebylo založeno pro prezentaci jeho odkazu. Důležitějším posláním MKG bylo ukotvení role a zásluh KSČ a Gottwald byl pouze jednou ze součástí tohoto konstruktu. Jak se v období normalizace celospolečensky projevil návrat ke Gottwaldově odkazu, tak se i jeho osoba více projevila $\mathrm{v}$ činnosti a konečně se objevila v propagaci MKG. Až $\mathrm{v}$ tomto období se vlastně dostala podobenka Gottwalda na vizuál tištěné propagace muzea nesoucího jeho jméno.

Přestože není cílem tohoto rozboru umělecko-historické hodnocení, tak je zřejmé, že plakáty MVIL mají obecně řečeno $v$ jednotlivých produktech vyšší úroveň uměleckého výrazu než MKG. Ovšem nároky užívané pro umělecko-historické hodnocení plakátů nejsou na řešené téma opravdu produktivně aplikovatelné. „Síla, kterou na nás působí, závisí především na výtvarném řešení, tj. na sladění jeho základního úkolu informovat, propagovat, poutat pozornost s požadavky kladenými na umělecké dílo." ${ }^{\text {95 }}$ Snad až na plakát MVIL z roku 1987 by ostatní neprošly sítem kritiky uměleckého díla. Jasně převažuje funkce „informovat a propagovat“. Poutání pozornosti je tak nějak omezeno na pouhou prrítomnost plakátu muzea na plánovitě určených zvláště poloveřejných místech, jak je tomu u politického plakátu. Ale i tyto plakáty k výročím jsou často ukázkou

95 VLČEK, Tomáš. Současný plakát. Praha: Odeon, 1979, vnitřní strana obálky. 


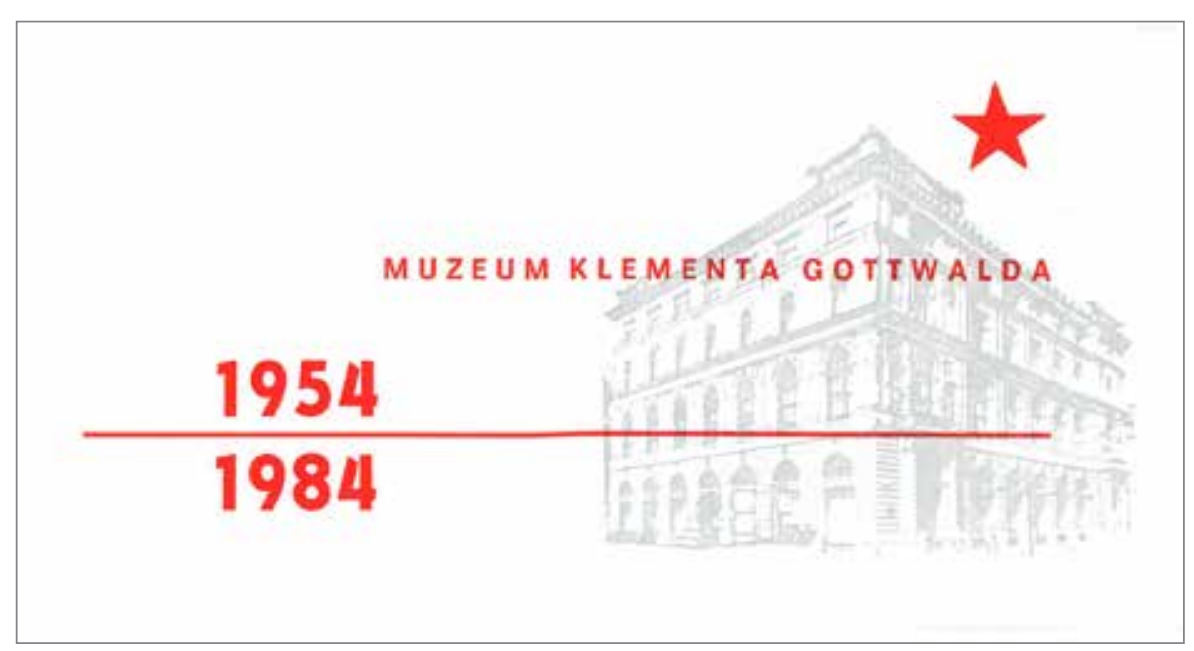

Obr. 7: Tisk k výročí Muzea Klementa Gottwalda, 1954-1984, album k 30. výročí vzniku MKG. Archiv Národního muzea, Fond Sbírka Muzea dělnického hnutí, nezpracováno.

kvalitního dobového designu. Je otázkou, zda určitá absence umělecké roviny autorského vkladu tvůrců vychází jen z předpokládané ideové kontroly, nebo se tím odráží určitá obsahová vágnost prezentovaného tématu stranických muzeí a sklony $\mathrm{k}$ faktografickému realismu. Z řady vzorků plakátů je ale zřejmé, že to neplatí obecně pro muzejní instituce a zvláště ne pro jejich výstavy.

\section{Použité zdroje: ${ }^{96}$}

Archiv a programové fondy České televize. Fond audiovizuálních záznamů.

Archiv Národního muzea. Fond Sbírka Muzea dělnického hnutí, nezpracováno.

Národní archiv v Praze. Fond 1065 - Ústav dějin KSČ, kart. 111, 113, 114, 115 a 116.

Národní muzeum, Historické muzeum. Sbírka Muzea dělnického hnutí, fond Plakáty (plakáty stranických muzeí a dalších kulturních institucí, části lístkových katalogů plakátů MKG).

Národní muzeum, Historické muzeum. Sbírka novodobých českých dějin, fond Plakáty (plakáty NM a dalších muzeí).

Moravská galerie v Brně. Sbírka Grafický design (plakáty MDH v Brně).

Jihočeské muzeum v Českých Budějovicích. Fond bývalého MDRH (plakáty MDRH v Českých Budějovicích).

96 Literatura pro srovnání tématu je uváděna pouze v poznámkách.
25 let Muzea Klementa Gottwalda. Praha: Muzeum Klementa Gottwalda, 1979.

BRABEC, Václav. 5 let musea Klementa Gottwalda. Praha: Muzeum Klementa Gottwalda, 1959. $14 \mathrm{~s}$.

BROŽ, Miroslav a Milan PEREMSKÝ. $M u-$ zeum Vladimíra Iljiče Lenina $v$ Praze - historie a současnost. Praha: Nakladatelství Svoboda, 1988.

Bulletin Moravské galerie v Brně č. 72. Brno: Moravská galerie v Brně, 2015. ISSN 0231-5793.

Československý lid a jeho kraj v životě, práci a zápasu. 1. vyd. Praha: Ministerstvo informací a osvěty, 1949.

Deset let Muzea dělnického revolučního hnutí jižních Čech v Českých Budějovicích (1975-1985). České Budějovice: Muzeum dělnického revolučního hnutí jižních Čech, 1985.

ELIÁŠOVÁ, Libuše. Gusta Fučíková a pozůstalost Julia Fučíka. In PODHAJSKÝ, František A. (ed.). Julek Fučík - věčně živý! 1. vyd. Brno: Host, 2010, s. 77-92. ISBN 978-80-7294-436-1.

FRANĚK, Otakar. Muzeum dělnického hnutí $v$ Brně. Brno: Krajské středisko státní památkové péče a ochrany přírody, 1975.

FRANĚK, Otakar (ed.). Rodný domek Klementa Gottwalda v Dědicích; světnička Klementa Gottwalda v Rousínově: [sborníček]. Praha: Muzeum Klementa Gottwalda, 1959.

FRANĚK, Otakar a Zbyněk STRÁNSKÝ. Památník Klementa Gottwalda v Dědicích: [průvodce]. Brno: Muzeum dělnického hnutí, 1978.
HANOUSEK, Jan. „A kdy se zase půjdeme podívat na velrybu?" Expozice a výstavy Národního muzea ve druhé polovině 20. století ve světle archivních pramenů [online]. 2018 [cit. 2019-08-23]. Dostupný z www: < https://is.cuni.cz/webapps/ zzp/detail/165394>. Vedoucí práce PhDr. Klára Woitschová, Ph.D.

HRON, Pavel (ed.). 20 let Muzea V. I. Lenina $v$ Praze. Praha: Muzeum V. I. Lenina, 1973.

JEŽEK, Alexandr a Milan PEREMSKÝ. Muzeum Vladimíra Iljiče Lenina $v$ Praze. Praha: Středočeské nakladatelství a knihkupectví v Praze, 1976.

LORIŠ, Jan a Jiří MÜLLER (eds.). Výstava dějin revolučních bojü: Praha - Památník osvobození. Květen-srpen 1949: Stručný průvodce. Praha: ÚV KSČ - kulturní a propagační odd., 1949.

Muzeum dělnického hnutí Brněnska: průvodce. Brno, 1958.

Muzeum Klementa Gottwalda. Praha, nedatováno.

Muzeum Klementa Gottwalda. Tematické okruhy sbírkotvorné činnosti Muzea Klementa Gottwalda $v$ oblasti dokumentace dějin revolučního dělnického hnutí a dějin Komunistické strany Československa. Praha, nedatováno.

Muzeum Klementa Gottwalda $v$ Praze. Expozice dějin revolučního dělnického hnutí a Komunistické strany Československa. Praha: ORBIS, nedatováno [po 1974].

Muzeum Klementa Gottwalda $v$ Praze. Expozice dějin revolučního dělnického hnutí a Komunistické strany Československaprůvodce. Praha: Panorama, 1982.

Muzeum Klementa Gottwalda. Katalog krátkých dokumentárních filmů. Praha: Muzeum Klementa Gottwalda v Praze, 1979.

Muzeum Klementa Gottwalda. Katalog stálé expozice I. Vytvoření Komunistické strany Československa a její boj za sociální a národní osvobození pracujícího lidu Československa. Praha, 1975.

Múzeum revolučnej tlače Klementa Gottwalda vo Vrútkách: Sprievodca po expozícii. Martin: Múzeum revolučnej tlače Klementa Gottwalda, 1986.

NOVOTNÝ, Karel. Průkopníci socialismu: průvodce expozicí $v$ národním kulturním památníku Kaštan. Praha: Obvodní národní výbor, 1979. 
ORIŠKOVÁ, Mária (ed.). Efekt múzea: predmety, praktiky, publikum. Bratislava: Afad Press, 2006. ISBN 80-89259-08-1.

Pět let Muzea dělnického hnutí Brněnska (1959-1964). Brno: Muzeum dělnického hnutí Brněnska, 1964.

Sborník výstavy dějin revolučních bojů. Praha: Kulturní a propagační oddělení sekretariátu ÚV KSČ, 1949.

SCHNEIDER, Evžen. Stručný průvodce expozicí Muzea dělnického revolučního hnutí jižních Čech v Českých Budějovicích. České Budějovice: Jihočeské muzeum, 1975.

SOMMER, Vítězslav. Angažované dějepisectví: stranická historiografie mezi stalinismem a reformním komunismem (1950-1970). 1. vyd. Praha: Nakladatelství Lidové noviny, 2011. České dějiny, sv. 2. ISBN 978-80-7308-378-6.

STRÁNSKÝ, Zbyněk a Josef Rudolf WINKLER. Pojd'te s námi do muzea. 1. vyd. Praha: Kraj. dům osvěty, 1959.

ŠANDA, Jaroslav a Anna MASARYKOVÁ (eds.). Český národ Rudé armádě: seznam děl výtvarného umění věnovaných českými umělci Rudé armádě z vděčnosti za osvobození a odevzdaných $k$ výročnímu dni založení Rudé armády 23. února 1946. Praha: Společnost pro kulturní a hospodářské styky s SSSR, 1946.

ŠTVERÁK, František. Schematismus $k$ dějinám Komunistické strany Československa (1921-1992): základní informace o ústředních orgánech a biografické údaje o vedoucích představitelích strany. 2. oprav. a rozšír. vyd. Praha: Národní archiv, 2018. ISBN 978-80-86712-87-1.
TÁBORSKÝ, Ondřej. Dějiny podle plánu. Politika dějin a paměti v normalizačním muzejnictví. In Radka ŠUSTROVÁ a Luba HÉDLOVÁ. Česká pamět: národ, dějiny a místa paměti. Praha: Academia, 2014, s. 279-328. ISBN 978-80-200-2411-4.

TOTHOVÁ, Jolana. Sbírka Muzea dělnického hnutí - rozsáhlý soubor předmětů, archiválií a knih. Muzeum: Muzejní a vlastivědná práce, 2017, roč. 55, č. 2 , s. 16-26. ISSN 1803-0386.

TOTHOVÁ, Jolana a Tomáš KAVKA. Zrod a místo stranických muzeí po roce 1948 s ohledem na fondy Muzea Klementa Gottwalda. In HUPKO, Daniel a Luděk BENEŠ (eds.). Dokumentácia „osmičkových" výročí v slovenských a českých múzeách. Rok 1918 a tie ostatné. Banská Bystrica: Zväz múzeí na Slovensku, 2018. ISBN 978-80-971748-7-3.

TRÁVNÍČKOVÁ, Markéta. Unikátní sbírky cedulí a plakátů Divadelního oddělení Národního muzea. Časopis Národního muzea. Řada historická, 2017, roč. 186, č. 1-2, s. 55-66. ISSN 1214-0627.

Výstava dějin revolučních bojů. Praha: Svět v obrazech, 1949. Aktuality v obrazech, sv. 8.

Výstava Třicet let KSČ. Praha: Ústav dějin KSČ, 1951.

Znamení doby = Signs of the times: sborník přednášek z mezinárodních sympozií Kultura, politika a společnost ve střední a východní Evropě 1945-2000: Moravská galerie v Brně 18.-19. 11. 1999, Manchester Metropolitan University 18. 3. 2000. Brno: Moravská galerie, 2003. ISBN 80-7027-124-8.

\section{JOLANA TOTHOVÁ}

Národní muzeum

Oddělení novodobých českých dějin

Praha, Česká republika

jolana_tothova@nm.cz

Jolana Tothová vystudovala obor Kulturně historická regionalistika se specializací stavební historie na Filozofické fakultě Univerzity J. E. Purkyně v Ústí nad Labem. Od r. 2004 pracovala na pozici památkář-historik v Národním památkovém ústavu, ú. o. p. v Ústí nad Labem, následně od r. 2017 je kurátorkou Sbírky Muzea dělnického hnutí v Národním muzeu. Věnuje se činnosti stranických muzeí, dlouhodobě také průzkumu a popularizaci propojení architektury a umění.

Jolana Tothová studied

Cultural History of Religion

with specialisation in building

history at the Faculty of Arts

of the University in Ústí nad Labem. Since 2004 she worked as a conservationist-historian in the National Heritage Institute in Ústí nad Labem and since 2017 she curates the Working Class Movement Museum Collection in the National Museum. She dedicates herself to the activity of political party museums and to long-term study and popularisation of the interconnection between architecture and art. 